\title{
Advanced Wastewater Treatment to Eliminate Organic Micropollutants in Wastewater Treatment Plants in Combination with Energy-Efficient Electrolysis at WWTP Mainz
}

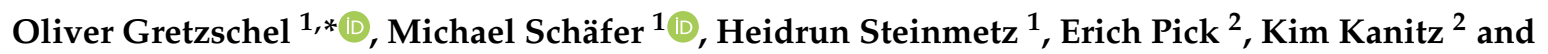 \\ Stefan Krieger ${ }^{3}$ \\ 1 Institute Water Infrastructure Resources, University of Kaiserslautern, Paul-Ehrlich-Straße 14, \\ D-67663 Kaiserslautern, Germany; michael.schaefer@bauing.uni-kl.de (M.S.); \\ heidrun.steinmetz@bauing.uni-kl.de (H.S.) \\ 2 Greenpeace Energy eG, Hongkongstraße 10, D-20457 Hamburg, Germany; \\ erich.pick@greenpeace-energy.de (E.P.); Kim.Kanitz@greenpeace-energy.de (K.K.) \\ 3 Hydro-Ingenieure Energie \& Wasser GmbH, Richard-Wagner-Straße 45, D-67655 Kaiserslautern, Germany; \\ s.krieger@hydro-ingenieure.de \\ * Correspondence: oliver.gretzschel@bauing.uni-kl.de
}

Received: 27 May 2020; Accepted: 6 July 2020; Published: 13 July 2020

\begin{abstract}
To achieve the Paris climate protection goals there is an urgent need for action in the energy sector. Innovative concepts in the fields of short-term flexibility, long-term energy storage and energy conversion are required to defossilize all sectors by 2040. Water management is already involved in this field with biogas production and power generation and partly with using flexibility options. However, further steps are possible. Additionally, from a water management perspective, the elimination of organic micropollutants (OMP) is increasingly important. In this feasibility study a concept is presented, reacting to energy surplus and deficits from the energy grid and thus providing the needed long-term storage in combination with the elimination of OMP in municipal wastewater treatment plants (WWTPs). The concept is based on the operation of an electrolyzer, driven by local power production on the plant (photovoltaic (PV), combined heat and power plant (CHP)-units) as well as renewable energy from the grid (to offer system service: automatic frequency restoration reserve (aFRR)), to produce hydrogen and oxygen. Hydrogen is fed into the local gas grid and oxygen used for micropollutant removal via upgrading it to ozone. The feasibility of such a concept was examined for the WWTP in Mainz (Germany). It has been shown that despite partially unfavorable boundary conditions concerning renewable surplus energy in the grid, implementing electrolysis operated with regenerative energy in combination with micropollutant removal using ozonation and activated carbon filter is a reasonable and sustainable option for both, the climate and water protection.
\end{abstract}

Keywords: case study; defossilization; energy transition flexibility; long-term energy storage; ozonation; power-to-gas; sewage treatment; water-energy-nexus

\section{Introduction and Background}

To achieve the Paris climate protection goals (temperature rise $<1.5^{\circ} \mathrm{C}$ [1]), there is an urgent need for action in the energy sector. To accomplish that goal a rapid expansion of renewable energy generation capacities is needed and the provision of flexibility, long-term energy storage and energy conversion to maintain stable operation of the energy grids is essential. This is mandatory to defossilize all sectors by $2040[2,3]$. Water management is already taking part here, but can take more ambitious 
steps. From a water management perspective, the elimination of organic micropollutants (OMP) is of increasing importance. Both aspects can be combined and solved in a holistic manner.

\subsection{Organic Micropollutants (OMP) in Wastewater}

The topic of OMP is one of the top priorities on the international agenda in water management for several years [4-8]. Wastewater treatment plants (WWTPs) are presenting one of the main pathways of OMP into the environment and surface water [9]. In Europe several countries are taking activities in treating OMP at WWTPs like Denmark, Finland, France, Sweden, Netherlands, Germany and Switzerland [10,11]. However, legal regulations are actually implemented only in Switzerland [12,13], other countries shy away from compelling measures. In Germany, handling of OMP is still very different among the federal states and but was taken up as part of the national federal stakeholder process. The results of the process were summarized in a report in March 2019 [14] and give for the first time a framework for advanced wastewater treatment at the federal level. Up to now, in some federal states a large number of WWTPs of different sizes have already been equipped with an advanced treatment step for the removal of OMP. In Europe, the most commonly used process technologies to remove OMP are ozonation or active carbon (AC) technologies [11,15].

\subsection{Sector Coupling and Energy Transition}

The ongoing worldwide energy transition from fossil to renewable energy production is shown by the global increasing capacity of renewables [16] with a yearly growth rate of $7.4 \%$ and a total power generation capacity of $2537 \mathrm{GW}$ at the end of 2019. The global share of renewable capacity is highest in Asia (44\%) and Europe (23\%) followed by North America (15\%) and South America (9\%) [17]. With an increasing share of renewables, sector coupling will become a central element of this transition process. It is defined as the integration of energy systems from different sectors, which are usually managed and optimized independently of one another via specific energy storage options. Relevant sectors are electricity, gas, heating, transport and the production of basic chemical materials [18]. Based on the electricity sector driven by renewables, power-to- $x$ technologies can supply the required transformation of energy to the other sectors to substitute fossil-based resources and lead to more stability of the system.

A large review of the possible role of WWTPs by means of sector coupling is given in [19]. Practical implementations and their impacts on the processes are depicted, discussed and evaluated. The results show significant synergies, e.g., using electrical energy surplus from the power grid (secondary control reserve, to offer system service: automatic frequency restoration reserve (aFRR)) to produce hydrogen and oxygen with an electrolyzer. Hydrogen can be used for long-term storage and oxygen for enhancing purification processes on the WWTP. Furthermore, storable methane gas can be produced at WWTPs, which can contribute to an implementation of local heating networks. As explained in detail in [19], an interconnection in many fields of different research sectors is given and it is shown that it is possible and reasonable for WWTPs to contribute with sustainable energy concepts to defossilization. Thus it can be assumed that many WWTPswill be able to support the energy transition with its gas potentials and flexibility options if suitable management concepts are applied (cf. [20,21]).

\section{WWTP Mainz}

\subsection{Description of the Plant}

The WWTP Mainz (Germany) is a mechanical-biological treatment plant for enhanced nitrogen and phosphorus removal with separate anaerobic sludge digestion. It treats the wastewater of approximately 225,000 inhabitants plus wastewater from industry, summing up to $375,000 \mathrm{PE}_{120}$ in 2017. The wastewater inflow amounts up to $55,000 \mathrm{~m}^{3}$ per day (average value) with peaks of $6300 \mathrm{~m}^{3}$ per hour. 
A simplified flow chart is given in Figure 1. The rain overflow basin is placed upstream of the inlet with a total volume of $18,700 \mathrm{~m}^{3}$ feeding the first treatment stage consisting of a four-lane screen, four aerated grit chambers and a primary sedimentation tank $\left(3700 \mathrm{~m}^{3}\right)$. The second stage consists of six activated sludge tanks $\left(4 \times 5200 \mathrm{~m}^{3}+2 \times 2600 \mathrm{~m}^{3}\right)$, each with five cascades, equipped with aeration panels and mixing devices. Nitrification and denitrification take place intermittently and alternately. Phosphate is chemically precipitated by two-point simultaneous precipitation (in the return sludge and the effluent of the activated sludge tanks). From the effluent of the activated sludge tanks the wastewater is pumped to twelve secondary clarifiers with an overall volume of $30,120 \mathrm{~m}^{3}$. Afterwards, the cleaned wastewater is discharged to the Rhine River.

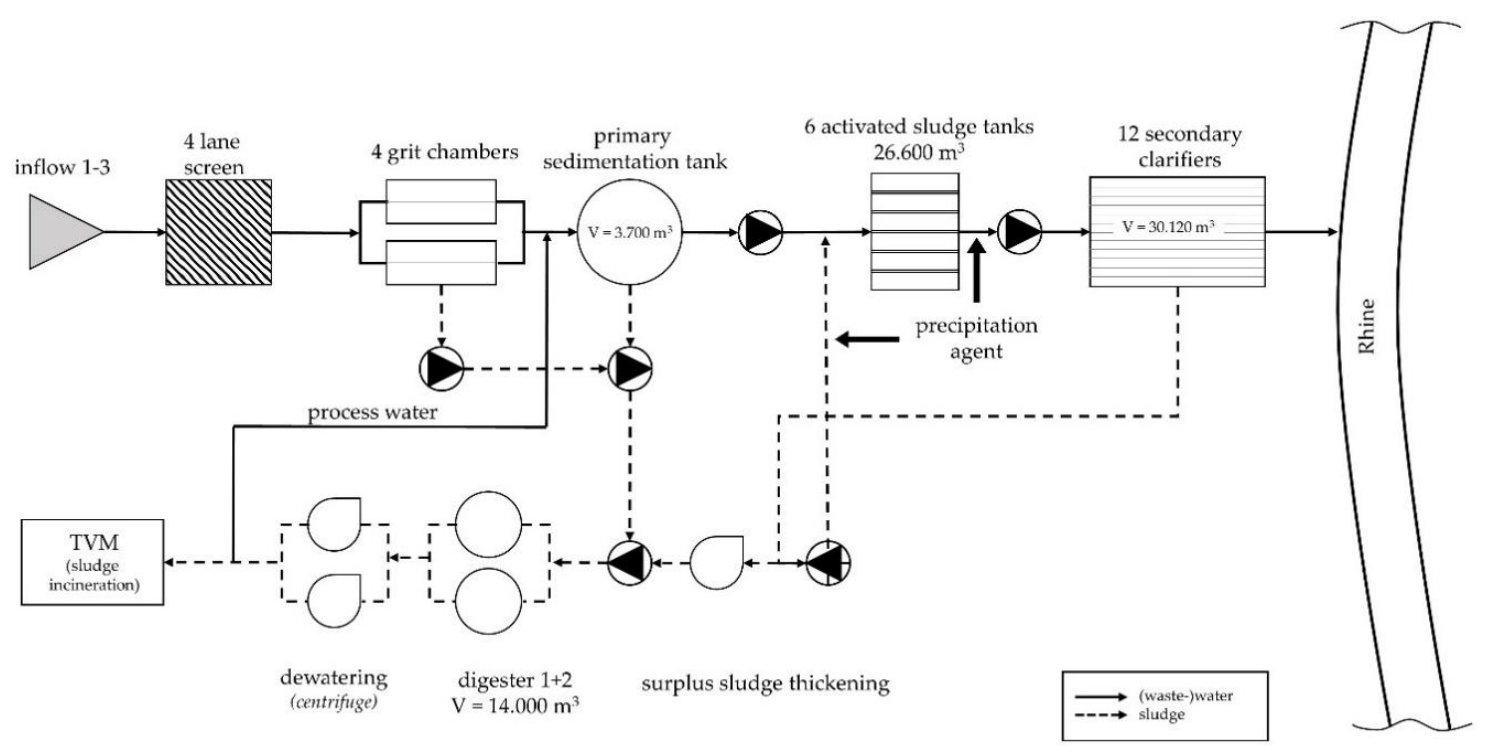

Figure 1. Simplified flow chart of the wastewater treatment plant (WWTP) Mainz.

Sewage sludge is anaerobically stabilized in two digesters with a total volume of $14,000 \mathrm{~m}^{3}$. The digested sludge is dewatered by centrifuges before incineration onsite (start of operations in second half of the year of 2020). Nearly $8900 \mathrm{Nm}^{3} / \mathrm{d}$ raw biogas corresponding to $23.7 \mathrm{~L} /(\mathrm{PE} \cdot \mathrm{d})$ are produced in the digesters and can be temporarily stored in two parallel operated low-pressure gas storage tanks with a volume of $6700 \mathrm{~m}^{3}$ [22]. The biogas is used in four combined heat and power plant (CHP) units with around 1.4 $\mathrm{MW}_{\mathrm{el}}$. Furthermore, the thermal energy of the cooling water from the CHPs is used via a heat exchanger to heat the digestion tanks and the operation buildings of the WWTP.

\subsection{Organic Micropollutants}

In order to get a rough insight into the micropollutant situation at the WWTP Mainz as a base for the planning process, one influent sample and five effluent samples (all as 24-h composite samples) were taken during dry weather flow and analyzed for approximately 120 micropollutants. The results of the analysis of these samples are available in Supplementary Materials Data S1. An extract of the results for 12 drugs and five X-ray contrast agents is shown in Figure 2. For a better evaluation and ranking, the inflow concentrations are compared with concentration values of 40 other municipal WWTP based on [23]. The effluent values are compared to concentrations measured on five municipal WWTP based on [24]. 


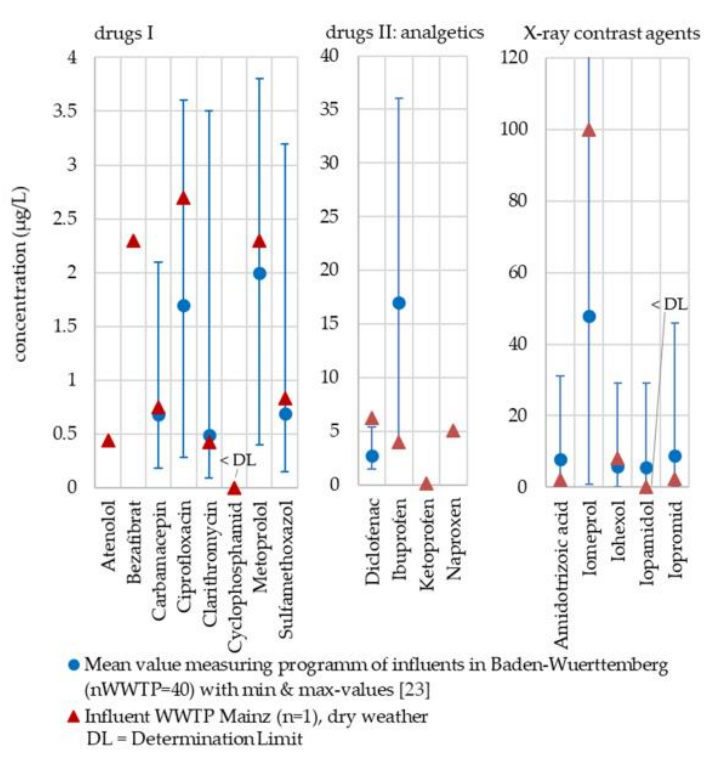

(a)
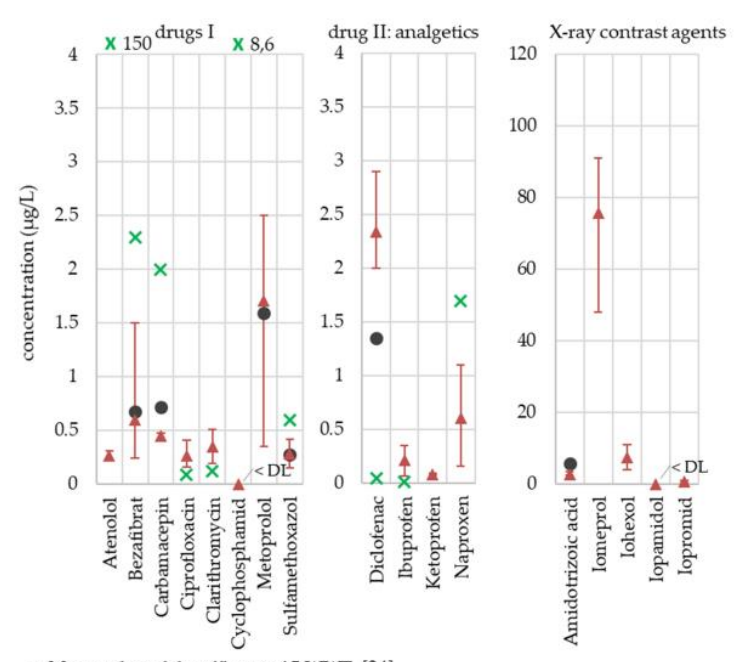

Mean value of the effluent of 5 WWT [24]

$\triangle$ Mean value of 5 effluent samples WWTP Mainz, dry weather, min- \& max-values $\times$ Value of the CQS [8] $\mathrm{DL}=$ Determination Limit

(b)

Figure 2. Micropollutant concentrations at WWTP Mainz compared to results from other WWTP: (a) Inflow values of WWTP Mainz compared to results in [23] and (b) effluent values of WWTP Mainz compared to values in [24] complemented by chronic quality standard (CQS)-values.

The inflow concentrations in Figure 2a show that the concentrations from five substances are close to the mean values reported in [23], the others are at least within the range between the minimum and maximum values of [23]. This demonstrates that the concentrations for OMP in the influent of the WWTP Mainz are within a typical range of other municipal WWTPs. Nevertheless some substances like the common widely used analgetic diclofenac (DCF; influent concentration of $6.3 \mu \mathrm{g} / \mathrm{L}$ ) occur in the upper concentration range, whereas the pain reliever ibuprofen can be found in a lower concentration range $(4 \mu \mathrm{g} / \mathrm{L})$ compared to the literature data from [23]. The X-ray contrast medium iomeprol has a concentration twice as high as the mean value of the measurements published in [23]. However, the other contrast media examined are in the lower part of the measuring range (e.g., amidotrizoic acid, iohexol and iopromid) or close to the determination limit (iopamidol).

Most substances measured in the effluent of the WWTP Mainz are within a typical range found on other WWTPs [24] (see Figure 2b). However, some substances show a different pattern. DCF reaches with an average concentration of $2.2 \mu \mathrm{g} / \mathrm{L}$ higher concentrations than the mean effluents concentrations described in [24]. An international review of DCF in municipal WWTPs [25] also confirms that DCF inflow concentration as well as effluent concentrations in Mainz are rather high, but are even found in higher concentrations on few WWTPs in Germany and worldwide [26].

Nevertheless, these results have to be regarded conditionally because

- the limited sampling only shows a snapshot and is not statistically assured;

- deviation between the concentrations found in Mainz and on other WWTPs might depend on regional differences in the application and prescription of substances.

The comparison of influent and effluent concentrations in Mainz shows the medium removal of DCF in the conventional wastewater treatment. This is in accordance with the removal rates quantified as "mainly in the scope of $21-40 \%$ " in [27].

Figure $2 \mathrm{~b}$ shows additionally the chronic quality standard (CQS) values in order to assess the ecotoxicological relevance of a substance. CQS is described as follows in [8]: "Chronic quality standards are recommended for water quality monitoring. They can be used for assessing pollution over an extended time period. For the continuous input of micropollutants from treated effluents, the chronic quality standard is particularly relevant and helps to protect the organisms against the consequences 
of long-term pollution". The value of the proposed CQS for DCF in Germany and Switzerland is $0.05 \mu \mathrm{g} / \mathrm{L}[8,28]$. In the Rhine River, one of the large rivers in Europe, the DCF concentration is already in the area of the CQS and exceeds the CQS seasonally and clearly at different measuring stations [29]. The specific situation at the measuring point Mainz is shown in Figure 3. The mean value of the measuring period 2010-2017 amounts to $0.047 \mu \mathrm{g} / \mathrm{L}$ [30] and is thus only marginally lower than the proposed CQS. Therefore, a real need for OMP removal is pointed out.

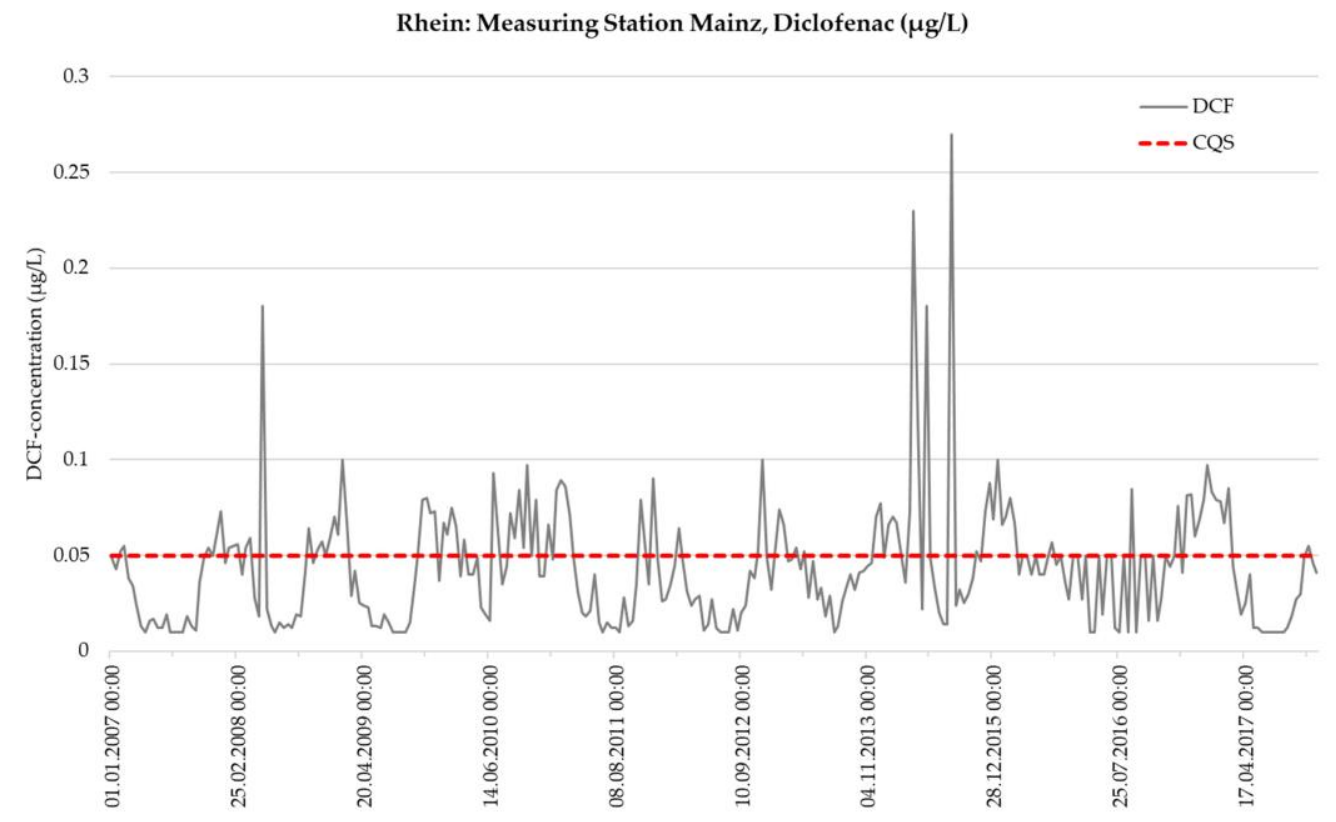

Figure 3. Concentrations of the analgetic diclofenac in the Rhine River [30].

\subsection{Energetic Situation and Upcoming Changes}

The WWTP Mainz has actually a total power consumption of $8200 \mathrm{MWh}_{\mathrm{el}} / \mathrm{a}$, corresponding to a specific power consumption of $21.9 \mathrm{kWh} / \mathrm{el} / \mathrm{PE} \cdot \mathrm{a})$. This is far below the median value of $35 \mathrm{kWh} \mathrm{el}_{\mathrm{e}} /(\mathrm{PE} \cdot \mathrm{a})$ of other comparable WWTPs in Germany [31] and characterizes the energetic efficiency of this WWTP. The electrical self-sufficiency rate averages actually around $78 \%$, which is realized by $227 \mathrm{MWh}_{\mathrm{el}} / \mathrm{a}$ produced by onsite photovoltaic (PV) power and $6173 \mathrm{MWh}_{\mathrm{el}} /$ a generated by onsite CHPs using biogas produced in the two digesters (see Figure 1). In the current situation only $81 \%$ of the total yearly biogas amount of 3,250,000 $\mathrm{m}^{3}$ /a with an energy content of $19,825 \mathrm{MWh}_{\mathrm{CH} 4} /$ a (heating value: $\left.6.1 \mathrm{kWh} / \mathrm{m}^{3}\right)$ can be used to produce electricity via CHPs $\left(\eta_{\mathrm{el}}=38.5 \%\right)$ onsite. Due to a dynamic energy demand of the WWTP and limited storage capacity for the biogas, ca. $19 \%\left(621,475 \mathrm{~m}^{3} / \mathrm{a} \cdot .6 .1 \mathrm{kWh} / \mathrm{m}^{3}\right.$ $3791 \mathrm{MWh}_{\mathrm{CH} 4} / \mathrm{a} \stackrel{\cdot 0.385}{\rightarrow} 1460 \mathrm{MWh}_{\mathrm{el}} / \mathrm{a}$ ) of the biogas, respectively, its energy content is not used onsite and needs to be flared because a conversion into electricity via CHP and feeding into the public power network is uneconomic due to low feed in compensations. As a consequence, $1800 \mathrm{MWh}_{\mathrm{el}} / \mathrm{a}$ have to be purchased from the regional power utility to ensure the continuous power supply of the plant. The here mentioned energetic indicators are summarized in Table 1.

In the second half of the year 2020 a new sewage sludge incineration plant (TVM-Thermische Verwertung Mainz, Mainz, Germany) will start operation at the site of the WWTP Mainz, processing sewage sludges from several WWTPs in the surroundings corresponding to a total capacity of nearly $2,400,000 \mathrm{PE}_{120}$. This will affect the energy balance and consumption for the operation of the WWTP Mainz: the processes of sludge dewatering and drying will then be integrated in the TVM system reducing the power consumption of the WWTP by the amount of $328 \mathrm{MWh}_{\mathrm{el}} / \mathrm{a}$. The sludge drying will be realized by the waste heat of the turbine of TVM, which will provide an electrical surplus power of up to $500 \mathrm{~kW}_{\mathrm{el}}$, producing $4000 \mathrm{MWh}_{\mathrm{el}} / \mathrm{a}$, used for the wastewater treatment. This will significantly 
change the current situation of external electricity procurement and the use of biogas for self-sufficiency purposes: a purchase of external power is no longer necessary. Launching the TVM, the theoretical power (energy) surplus onsite will increase to $3988 \mathrm{MWh}_{\mathrm{el}} / \mathrm{a}$ (corresponding to 10,357 $\mathrm{MWh}_{\mathrm{CH} 4} / \mathrm{a}$ biogas). The summarized energy balance is illustrated in Table 1.

Table 1. Energetic situation based on annual average values of the WWTP Mainz before and after the start of operation of the sludge incineration plant.

\begin{tabular}{|c|c|c|c|c|}
\hline $\begin{array}{l}\text { Type of } \\
\text { Indicator }\end{array}$ & Specification & Unit & $\begin{array}{c}\text { Status- } \\
\text { Quo } 2019\end{array}$ & $\begin{array}{l}\text { Expected } \\
\text { in } 2020\end{array}$ \\
\hline $\begin{array}{c}\text { Power } \\
\text { consumption }\end{array}$ & Total power consumption of WWTP & MWhel/a & -8200 & -7872 \\
\hline \multirow{3}{*}{$\begin{array}{l}\text { Biogas } \\
\text { indicators }\end{array}$} & Produced amount of biogas onsite & $\mathrm{m}^{3} / \mathrm{a}$ & $3,250,000$ & $3,250,000$ \\
\hline & Energy content of biogas ${ }^{1}$ & $\mathrm{MWh}_{\mathrm{CH} 4} / \mathrm{a}$ & 19,825 & 19,825 \\
\hline & $\begin{array}{c}\text { Theoretical power generation from biogas } \\
\text { via } \mathrm{CHP}^{2}\end{array}$ & MWhel/a & 7633 & 7633 \\
\hline \multirow{5}{*}{$\begin{array}{c}\text { Power } \\
\text { production } \\
\text { and purchase }\end{array}$} & Biogas use in CHP & MWhсH4/a & 16,034 & 9468 \\
\hline & Real power generation of $\mathrm{CHP}$ & MWhel/a & +6173 & +3645 \\
\hline & PV power generation & $\mathrm{MWhel} / \mathrm{a}$ & +227 & +227 \\
\hline & $\begin{array}{c}\text { Purchased power from public electricity } \\
\text { network }\end{array}$ & MWhel/a & +1800 & 0 \\
\hline & net Power from TVM ${ }^{3}$ & MWhel/a & 0 & +4000 \\
\hline \multirow[t]{2}{*}{ Surplus Power } & $\begin{array}{l}\text { Corresponding surplus biogas }{ }^{4} \text { (flared in } \\
\text { the status quo) }\end{array}$ & $\mathrm{MWh}_{\mathrm{CH}} / \mathrm{a}$ & +3791 & $+10,357$ \\
\hline & Theoretical resulting power surplus on site & MWhel/a & +1460 & +3988 \\
\hline
\end{tabular}

1: calculated on the basis of a heating value of biogas of $6.1 \mathrm{kWh} / \mathrm{m}^{3} ;^{2}$ : calculated on the basis of the biogas amount and an electrical efficiency of the combined heat and power plant $(\mathrm{CHP})$ unit with $38.5 \%$ and a heating value of biogas of $6.1 \mathrm{kWh} / \mathrm{m}^{3}{ }^{3}{ }^{3}$ : electrical surplus power of TVM after electrical supply of internal TVM processes (including dewatering of sludge). ${ }^{4}$ : calculated on the basis of an electrical efficiency of the CHP unit with $38.5 \%$.

This expected amount of surplus biogas (Table 1) of 10,357 $\mathrm{MWh}_{\mathrm{CH} 4} /$ a generated onsite should be used under a holistic point of view and thus under aspects of energy storage and energy efficiency. Flaring of biogas as well as the conversion into electricity due to a full (local) gas storage has to be avoided because this will lose the flexibility and therefore energy-efficient properties of the renewable biogas. This is why a forward-looking energy-concept was in demand.

\section{Practical Implementation: The "Arrived" Project}

\subsection{Integrated Concept}

The aim of the project was to equip a municipal WWTP with an electrolysis and an advanced treatment step for the removal of OMP and to operate for the first time both process stages together, just using renewable energy sources.

On the one hand, electrolysis provides oxygen as the starting product for ozone generation, needed for ozone treatment of the wastewater to remove OMP. The ozonated wastewater is then led to a biologically activated and granulated active carbon filter (GACF) to reduce possible transformation products (Figure 4). This combination of OMP elimination processes has already been successfully demonstrated in several research projects [32-34] and has been investigated since 2017 in the frame of two pilot projects at the Paderborn WWTP $\left(30,000 \mathrm{PE}_{120}\right)$ [15] and the Weißenburg WWTP $\left(35,000 \mathrm{PE}_{120}\right)$ [35]. This technology is also operated at WWTP Altenrhein $\left(120,000 \mathrm{PE}_{120}\right)$ since 2019 [15] and proposed as combined treatment technology for the removal of OMP in Sweden [36]. However, up to now this combination is not implemented on a WWTP with a capacity of $375,000 \mathrm{PE}_{120}$ and connected to the energy market as it is planned for WWTP Mainz.

On the other hand, hydrogen generated by electrolysis can be used in different ways and is usually the much more valuable product. The natural gas infrastructure (NGI) acts as a long-term storage. Thus, particularly the direct feed into the natural gas grid of the local gas grid operator (Mainzer Stadtwerke, Mainz, Germany) may be considered due to a favorable location to the NGI. One focus of 
its use is the marketing of hydrogen (produced by the power-to-gas (PtG) technology) to the heating sector to replace natural gas in the public gas grid as an important contribution and component for the energy transition.

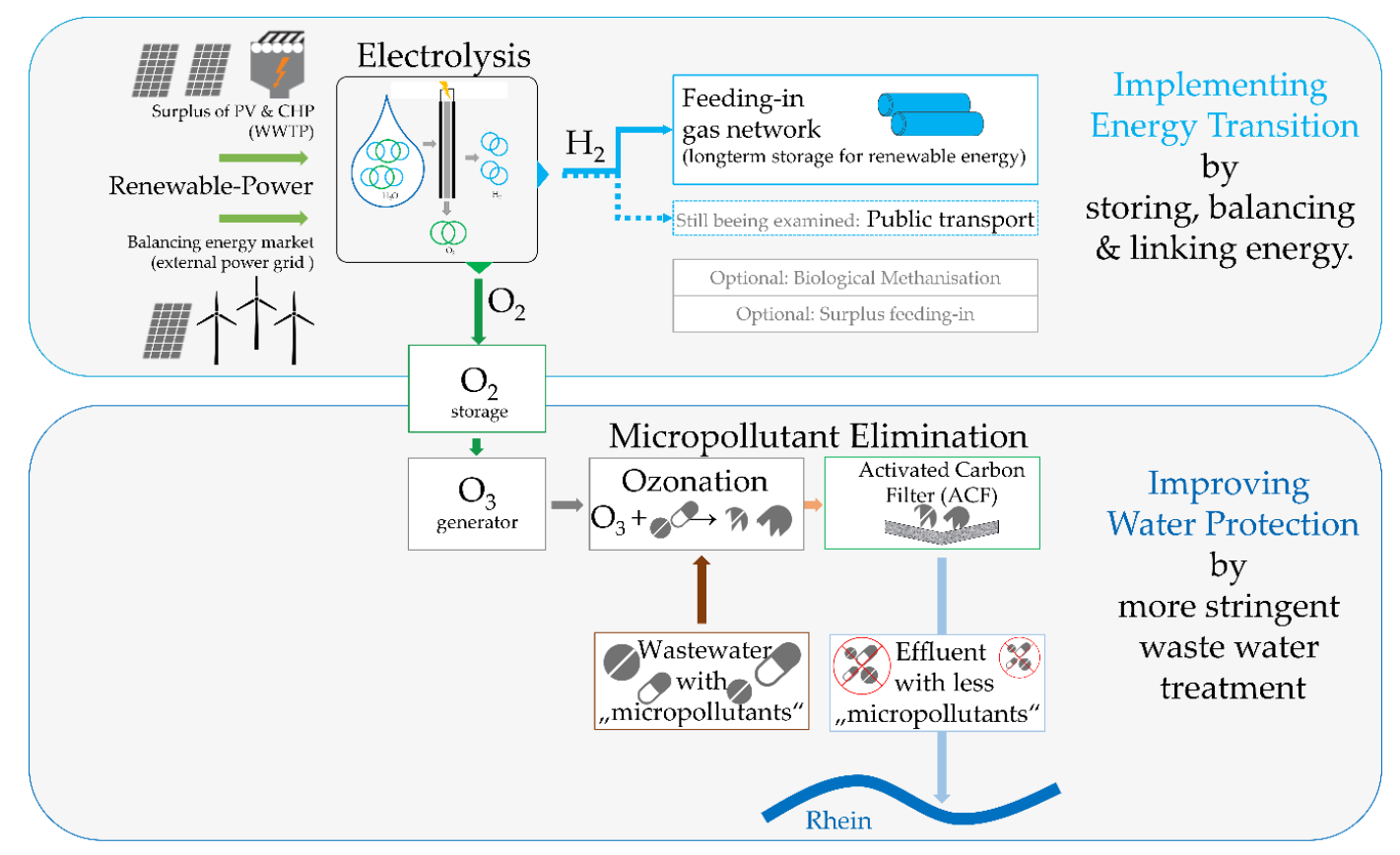

Figure 4. Process chain of the "arrived" project.

In addition to the feed-in into the natural gas grid the planned project also considers the use of $\mathrm{H}_{2}$ in the mobility sector and the public transport system of the city of Mainz (hydrogen buses).

At a later point, methanation with the $\mathrm{CO}_{2}$ from the flue gas of TVM or the $35 \%$ constituent of $\mathrm{CO}_{2}$ in the biogas could be a further option in the future.

The process chain of the above-described concept is shown in Figure 4. Before implementation two feasibility studies were conducted determining the planning constraints for the construction of such a system and demonstrating the feasibility for Mainz [22,37]. Both studies combine the investigations into the two innovative processes of micropollutant elimination and integration of a WWTP into the energy grid and their combination. Concerning WWTPs, especially for the last-mentioned area of electrolysis, there is only little experience when using surplus power and grid system services. In comparison to other initiatives, the challenge lies in coupling a sustainable energy concept with the removal of OMP. Experiences made in the single sectors were transferred and adapted to the specific local conditions of the WWTP Mainz. The result shows that the overall concept is sustainable, innovative and energy-efficient.

In the outcome of the studies, implementing an advanced treatment step for the removal of OMP for $89 \%$ of the wastewater stream (see Section 4.2.1), combined with an electrolyzer with an electrical capacity of 1.25 MW [22] (see Section 4.3) was proposed. This capacity enables a sufficient production of oxygen for ozonation and also the sustainable use of the energy surplus onsite (see Section 2.3).

The set-up of the new concept leads to a complex energetic situation with different given or fluctuating power generators and sources of renewable energy (a new photovoltaic (PV) will be installed, the TVM delivers surplus energy (see Table 1), temporarily available energy from the power grid to offer system service) and consumers (several devices on the WWTP, a new electrolyzer). No additional conventional electricity should be required for the cleaning process and an energy-efficient and sustainable generation of oxygen should take place. This will enable the self-generated electricity to be used locally and, in an energy-efficient manner under the very complex energetic conditions of a WWTP of such a size. 
This requires a precise control of the flexible power generators $(\mathrm{CHP})$, which cannot be ensured manually, but with the support of innovative software concepts and technology. Therefore, the establishment of storage and CHP management is planned to ensure the most regenerative and sustainable supply of the overall concept. The software aims to optimize the use of the biogas in the $\mathrm{CHP}$ and the gas storages for oxygen and hydrogen.

\subsection{Objectives and Environmental Impact}

The project pursues several objectives on two levels causing different positive environmental effects. Level 1: contribution to the energy transition (thus, positive effects on climate protection):

- Expansion of renewable energies on site through extension of the PV plant.

- Provision of short-term flexibility: integration of fluctuating renewable energy, and supply of system services in the form of aFRR (secondary control reserve).

- Sector coupling: integration of the WWTP in the energy market (hydrogen feed-in into the gas grid, hydrogen for public transport, gas storage and CHP management).

- Substitution of fossil fuels in different areas (gas and heat market, public transport and on-site of the WWTP).

- Coupling the regenerative energy generation on site with the advanced wastewater treatment to be implemented for the removal of OMP.

- Increasing resource efficiency by the use of the oxygen generated during electrolysis as the starting product for ozone production.

Level 2: improving water quality:

- Further reduction of OMP in the effluent of the WWTP by the innovative coupling of ozonation and GACF in combination (see Section 4.2) with resource-efficient operation of this process stage (see above) beyond the state of the art.

- Further reduction of phosphate and solid substances emissions into the Rhine River (see Section 5.1).

\section{Planning Principles, Boundary Conditions and Results of the Feasibility Studies}

\subsection{Energetic Environment}

In an ideal case, electrolyzers are operated with green volatile surplus energy. Both products should be used afterwards, hydrogen for energy purposes and, in the described case, sufficient oxygen should be available for the ozonation (see Section 4.3.3). To evaluate the energetic situation, a detailed analysis of the regional energetic environment of the WWTP as the location for the electrolyzer was carried out examining different hydrogen distribution paths, with a focus on feeding hydrogen into the natural gas grid. Additionally, the availability of renewable surplus energy, e.g., from wind or solar power plants was investigated.

Due to current German technical regulation, the maximum proportion of hydrogen in the natural gas grid is 10 vol.- $\%$ under favorable conditions [38]. Depending on technical restrictions local authorities can require lower proportions. In the case of Mainz the gas grid operator and Mainz municipal utility company determined that it is feasible to feed-in part of the produced hydrogen, but only up to 2 vol.- $\%$ of the gas flux in the grid. A higher amount is actually not possible, because of industrial and chemical processes nearby, which are using natural gas from the grid and would have problems with high amounts of hydrogen.

Regarding the availability of the temporarily renewable surplus energy of wind and PV power, the situation in Mainz is rather unfavorable. Due to the electricity demand in the Mainz region, no regional renewable energy surplus situations are to be expected in the near future.

Therefore, a location-specific electricity supply with renewable energy for the electrolyzer had to be ensured integrating fluctuating PV electricity (onsite) and a more flexible power supply by the 
CHP. Furthermore, the electrolyzer at WWTP can offer system services in the form of aFRR (secondary control reserve). An important aspect of the energy transition is the supply of system services based on renewable energy. Until now, conventional power plants mainly offer system services like frequency stabilization and load management. In a renewable future, this must be provided also by renewable energies and its flex options. Due to the feed-in capacity into the gas grid in Mainz, only discontinuous system services in the form of aFRR (secondary control reserve) are possible to be offered.

The emerging procedural changes at WWTP (commissioning of the TVM, relocation of sludge dewatering and drying) and the associated effects on the energy balance (see Section 4.5) need to be considered in the concept development as well. Furthermore, possibilities to increase the local renewable power generation by expansion of the PV capacity on the WWTP site were analyzed.

\subsection{Organic Micropollutant Elimination}

The reduction of OMP can be realized by different technologies: Oxidative technologies such as ozonation and advanced oxidation processes, adsorptive technologies like powdered activated carbon and granulated activated carbon (GAC) or physical technologies like nanofiltration and reverse osmosis $[11,36]$. Among these, ozonation and adsorptive technologies are most common. Physical technologies and advanced oxidation processes are the most cost intensive [39] and less proven at the technical scale and were therefore not considered in this project. Ozonation was compulsive in order to use the oxygen produced during electrolysis.

For the WWTP Mainz the micropollutant removal unit is designed as a two-step treatment with an ozone stage and a granulated active carbon filter (GACF) stage in series, treating the effluent of the secondary clarification. The advantage of combining both processes are as follows [36,40]:

- Increasing cleaning performance compared to one-step processes: in comparison to a pure ozone or GACF plant, both elimination mechanisms, oxidative degradation and GAC adsorption with their respective strengths are used for the removal of OMP. This effectively eliminates a wider range of micropollutants.

- Cleaning performance concerning micropollutant removal: depending on the desired elimination of various key substances, the ozone dosing in combination with the bed volume of the GAC can be adjusted.

- Reduction of the resource consumption for both stages and possibly the operating costs: Compared to single-stage ozonation or GAC processes, significantly lower ozone dosing and higher GAC bed volumes can be achieved. This reduces the resource consumption for each level.

\subsubsection{Treated Amount of Wastewater}

The treated amount of wastewater is a central design parameter for the advanced treatment step on the one hand influencing significantly the total elimination of OMP, on the other hand having a high impact on the investment costs. Therefore, a compromise between both aspects has to be found.

For the WWTP Mainz a maximum flow of $800 \mathrm{~L} / \mathrm{s}$ was scheduled for the final expansion. This exceeds the maximum dry weather inflow $Q_{d, h, m a x}$ of $760 \mathrm{~L} / \mathrm{s}$ and ensures that the complete dry weather and large parts of the rainwater inflow will be captured and treated. With the maximum flow of $800 \mathrm{~L} / \mathrm{s}$ around 17.8 million $\mathrm{m}^{3} / \mathrm{a}$ can be treated, corresponding to $89 \%$ of the annual wastewater volume.

\subsubsection{Plant Design}

The ozone reactor is designed for a retention time of 20 minutes, for the maximum flow of $800 \mathrm{~L} / \mathrm{s}$, resulting in a $960 \mathrm{~m}^{3}$ volume. The reactor consists of three lines each having a dimension of $\mathrm{L} \times \mathrm{W} \times \mathrm{D}=13.5 \mathrm{~m} \times 4.0 \mathrm{~m} \times 6.0 \mathrm{~m}$ (arrangement see Figure 5). 


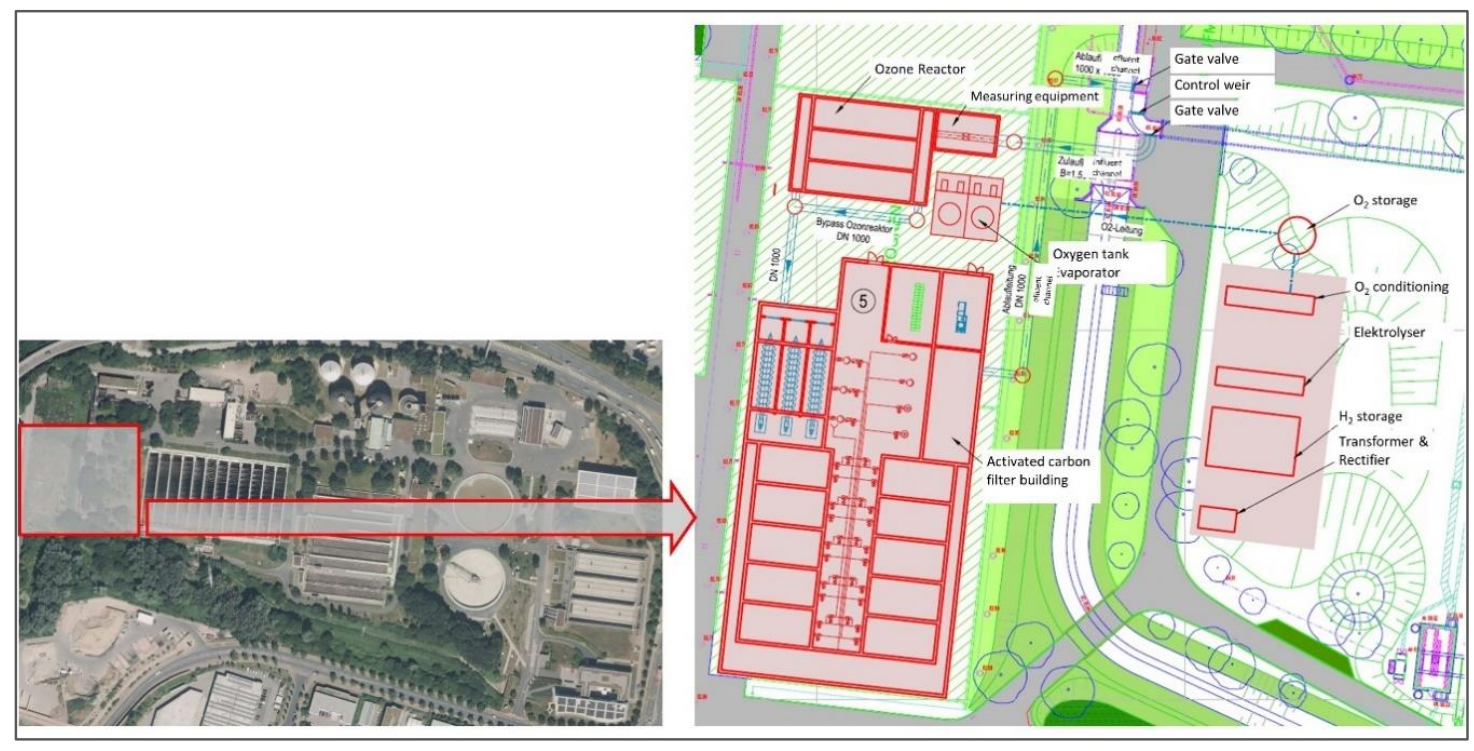

Figure 5. Aerial view of WWTP Mainz (www.geoportal.rlp.de; “Data license Germany—attributionVersion 2.0" referring to the license text available at www.govdata.de/dl-de/by-2-0; left side) and extract of a side plan with the new system components (right side) [41].

The ozone requirement depends on the treated flow and on the composition of the wastewater, where mainly the nitrite concentration of the feed flow is important. Actually the effluent of the WWTP Mainz comprises of partially increased nitrite concentrations attributed to high ammonium loads in the process water. In order to disburden the biological treatment step and thus reduce the effluent nitrite concentrations, a deammonification step for process water treatment was planned to be set up. For both scenarios (actual nitrite concentration and nearly no nitrite in the effluent) the ozone requirement was calculated and averages between 86.2 (status quo) and $53.1 \mathrm{kgO}_{3} / \mathrm{h}$ (no nitrite in the feed flow; further information see Appendix A). The produced gas from the ozone generator usually containing an ozone mass fraction of $10 \%$, thus $1 \mathrm{~kg}$ of $\mathrm{O}_{3}$ will be produced from $10 \mathrm{~kg}$ of $\mathrm{O}_{2}$. The average oxygen requirement will be therefore in the range between 2068 (status quo) and $1275 \mathrm{kgO}_{2} / \mathrm{d}$ (no nitrite in the feed flow).

The GACF cells were designed for a contact time of $20 \mathrm{~min}$ and a filter speed of $6 \mathrm{~m} / \mathrm{h}$, based on the maximum flow of $800 \mathrm{~L} / \mathrm{s}$. This resulted in a number of 10 filter cells with a dimension of $\mathrm{L} \times \mathrm{W}=9.6 \times 5.0 \mathrm{~m}$. The filter bed height is $2 \mathrm{~m}$. The total filter area was thus designed with $480 \mathrm{~m}^{2}$ (arrangement see Figure 5).

\subsection{Electrolysis}

\subsubsection{Sustainable Operation Options}

The electrolyzer should provide the oxygen required for ozonation and produce hydrogen for feed-in into the natural gas grid and for use in public transport. Whether an electrolysis operation is energy-efficient depends primarily on the mode of operation and the power supply. Continuous operation under a full load, which does not consider the current power grid situation or the fluctuating feed-in of renewable energies, does not support the energy transition due to its rigid additional load. In contrast, such a mode of operation rather damages the energy transition and causes more emissions of $\mathrm{CO}_{2}$. If the hydrogen would be produced with the conventional electricity mix, the greenhouse gas emissions would currently be about three times higher than the emissions from steam reforming [42]. Greenhouse gas emissions can only be reduced by supplying the electrolyzer with green electricity in combination with a flexible operating mode. The following modes of operation can be considered an energy transition supporting electrolysis operation: 
1. The use of renewable surplus energy in the power grid/reaction to the curtailment of renewable energy systems,

2. The use of a negative residual load caused by fluctuating renewable power,

3. The structuring of fluctuating renewable energies for integration in renewable energy portfolios or for sales to consumers,

4. Participation in the balancing power market/system services using renewable energy (in combination with points 1., 2. and 3.).

In a $100 \%$ renewable electricity system and alone in the context of point 1 . to 3 . it is assumed that an electrolyzer will have approximately 2500 full load hours [43].

\subsubsection{Operating Concept}

The analysis of the energetic environment (see Section 4.1) has shown that bottlenecks in the distribution grid or surplus energy from the curtailment of renewable energy plants are not to be expected in the region around WWTP Mainz in the near future. Furthermore, the analysis points out, that both, the structuring of fluctuating renewable energies and the reduction of forecast deviation of fluctuating renewable energies onsite, can be carried out more efficiently for the existing CHP units than the electrolyzer. Since offering a primary energy control reserve alone is not seen as a sustainable operation mode (see above) and due to the limited feed-in capacity into the gas grid, this system service for the power grid is not possible. Therefore, the only operation modes within the framework are expansion and integration of a new PV plant combined with the secondary control reserve aFRR.

To calculate the power consumption through aFRR, the provided system services of the years 2017 and 2018 were analyzed. The analysis shows that about $40-50 \%$ of the time aFRR is called. Today, the negative secondary control power is advertised daily in $4 \mathrm{~h}$ blocks, whereby the bid must be divided into performance and work price. To achieve high full load hours for the electrolyzer in order to reduce the specific fixed cost per $\mathrm{kWh}$ of hydrogen generated, a successful offer strategy for the working price must be developed. If the offer strategy places the electrolyzer in the lowest one to five percent of the merit order in each tender, around 3500 full load hours ( $40 \%$ of $8760 \mathrm{~h}$ a year) of the electrolyzer can be reached. It must be considered that the actual calls by aFRR depend on the offer strategy and can therefore deviate from the quantities assumed here.

In order to react to the secondary control signal as quick as possible a permanent minimum load of approximately $20 \%$ of its capacity, the minimal load of the electrolyzer, is needed.

This base load of the electrolyzer has to be covered with the local power production of fluctuating PV, the additionally installed PV plant onsite and the CHP units, which will supply the rest of the power needed. This is possible, as soon as the TVM is put into operation and therefore less biogas is needed to provide the electricity demand of the WWTP. The favorable maximum production of the PV plant matches the base load of the electrolyzer ( $20 \%$ of the capacity). Altogether, the power supply of the electrolyzer will not reduce the renewable energies (RE) in the power grid. The addition of PV onsite provides renewable electricity for the electrolyzer and therefore reduces the need for electricity from the grid.

Figure 6 shows an example of electricity consumption for the electrolyzer for a week in summer, in which the locally generated PV electricity at the WWTP Mainz would be included.

Simulation results of the energy consumption of the electrolyzer at WWTP showed that about $15 \%$ of the energy consumption could be covered by the already existing and newly planned PV plants on site and 34\% from CHP electricity. Approximately 50\% of the electrolyzer's power calls were made up of system services, the energy requirement of which, due to the short-term nature, mostly comes from the supply of green electricity from the grid. Since PV plants are already installed on the appropriate roof areas at the buildings of WWTP Mainz, the additional PV will be installed via an innovative construction above the secondary clarifiers, resulting in a double use of a portion of the WWTPs area (waste water treatment and power generation). 


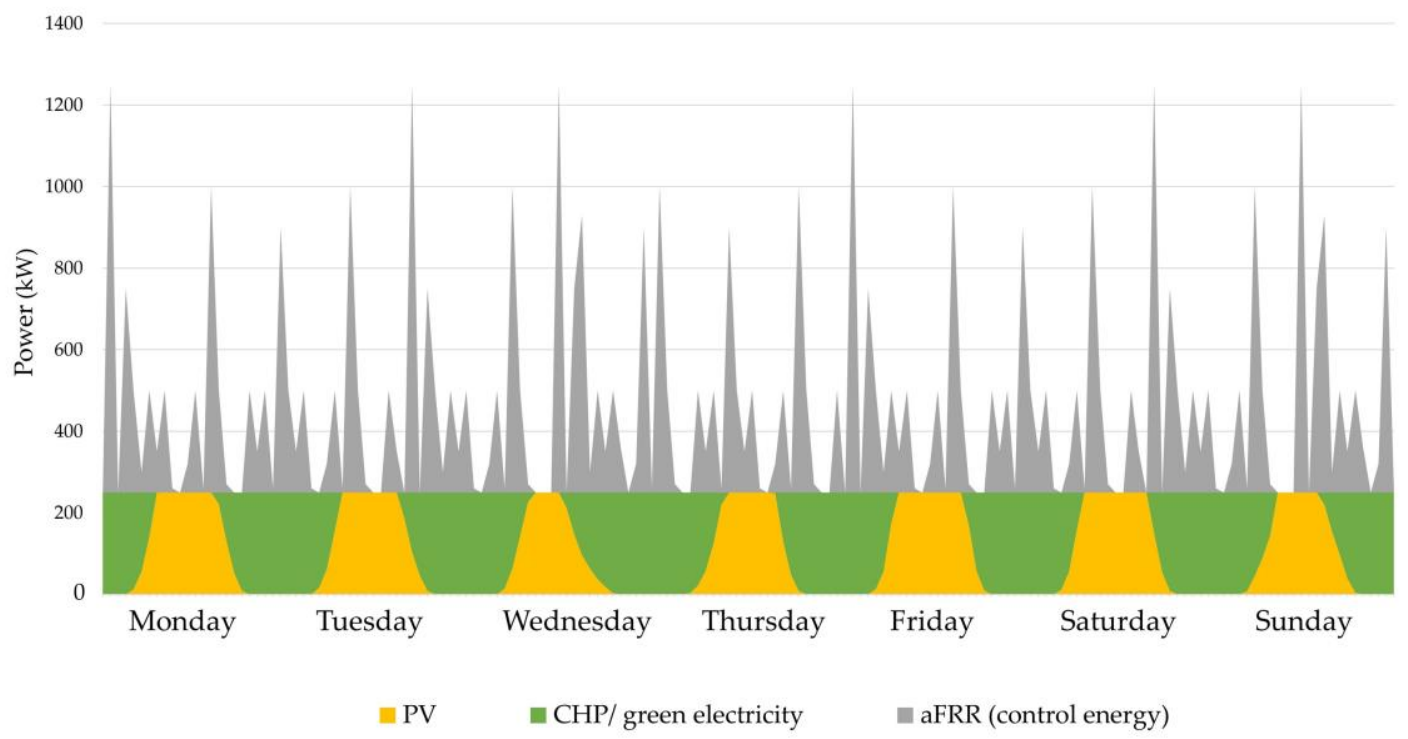

Figure 6. Example of electricity consumption for the electrolyzer in a summer week [41].

\subsubsection{Hydrogen and Oxygen Production}

A 1.25 MW electrolyzer provided the sustainable production of hydrogen $\left(\mathrm{H}_{2}\right)$ and the production of oxygen $\left(\mathrm{O}_{2} ;\right.$ cf. Table 2$)$. The efficiency of converting electricity to hydrogen was assumed as $68 \%$ based on manufacturer specifications and [44].

Table 2. Characteristics and performance data of the 1.25 MW electrolyzer.

\begin{tabular}{ccc}
\hline Characteristics & Amount & Unit \\
\hline Power & 1.25 & $\mathrm{MW}$ \\
Hours of operation $20 \%$ band & 8585 & $\mathrm{~h} / \mathrm{a}$ \\
Full load hours & 3500 & $\mathrm{~h} / \mathrm{a}$ \\
$\mathrm{O}_{2}$ production $(20 \%$ band $)$ & 292,000 & $\mathrm{~kg} / \mathrm{a}$ \\
$\mathrm{O}_{2}$ production $(\mathrm{aFRR})$ & 307,569 & $\mathrm{~kg} / \mathrm{a}$ \\
Total $\mathrm{O}_{2}$ production & 599,569 & $\mathrm{~kg} / \mathrm{a}$ \\
$\mathrm{H}_{2}$ production & 2975 & $\mathrm{MWh} / \mathrm{a}$ \\
\hline
\end{tabular}

The maximum oxygen requirement for the advanced treatment step is around $150 \mathrm{kgO}_{2} / \mathrm{h}$ and on average around $53 \mathrm{kgO}_{2} / \mathrm{h}$ or $465,206 \mathrm{kgO}_{2} / \mathrm{a}$ (see Section 4.2.2) after reducing the nitrite concentration in the effluent of the WWTP (cf. Table 3, additional and more detailed information see Appendix A). With the operating concept presented above, the base load of $20 \%$ of the electrolyzer's capacity (see Table 2) covers approximately $60 \%$ of the average oxygen demand for ozonation. The residual required oxygen has to be generated via discontinuous calls of control reserve (aFRR) and is temporarily stored in an oxygen storage tank (possibly supplemented by a backup liquid oxygen tank).

Table 3. Oxygen requirement of the advanced treatment for OMP reduction.

\begin{tabular}{ccc}
\hline & Amount & Unit \\
\hline specific oxygen demand for ozone production & 10.0 & $\mathrm{mgO}_{2} / \mathrm{mgO}_{3}$ \\
maximum required amount of oxygen & 149.1 & $\mathrm{~kg} \mathrm{O}_{2} / \mathrm{h}$ \\
average required amount of oxygen & 53.1 & $\mathrm{~kg} \mathrm{O}_{2} / \mathrm{h}$ \\
\hline
\end{tabular}




\subsection{Interface $\mathrm{O}_{2}$ Storage}

The central coupling element between the two usually separately operated technologies for OMP removal on the one hand and electrolysis on the other hand is oxygen storage with upstream $\mathrm{O}_{2}$ treatment.

The necessary inlet pressure for $\mathrm{O}_{2}$ at the ozone generator is at least 6 bar. Depending on the manufacturer, the pressure of the oxygen generated by PEM electrolysis varies from unpressurized to 10 bar (for electrolyzers with an electrical power greater than $500 \mathrm{~kW}$ ) and up to 30 bar (for electrolyzers with an electrical power less than $500 \mathrm{~kW}$ ) [45,46]. An $\mathrm{O}_{2}$ outlet pressure of 10 bars was assumed for the electrolysis provided at the Mainz WWTP. 10 bars were chosen because this pressure is easier to handle for manufacturers and more economical prices compared to higher pressures are expected.

The co-product oxygen of the electrolysis will be saturated with water and must be dried before storage. This can be realized with the same technology applied for the drying of hydrogen described in [47]: drying is realized in two steps. A gas-cooling-drying separates a high quantity of water via condensation followed by a temperature change adsorption.

If oxygen is considered to be an ideal gas in the relevant pressure range, the storage volume for the average daily requirement of $\mathrm{O}_{2}$ (basing on $1275 \mathrm{~kg} / \mathrm{d}$ ) will be provided in the form of a storage tank with a volume of $100 \mathrm{~m}^{3}$

\subsection{Energetic Situation after Implementation of the Concept}

The energetic situation after implementation of the concept and operation of the incineration plant will be influenced by the power consumption of the advanced wastewater treatment step $(-1240 \mathrm{MWh} / \mathrm{a})$ as well of the operation of electrolysis $(-2146 \mathrm{MWh} / \mathrm{a}$ for base load operation powered from onsite PV and CHP; $-2229 \mathrm{MWh} / \mathrm{a}$ for aFRR operation powered from the grid), and the generation of additional renewable PV power $\left(500 \mathrm{~kW}_{\mathrm{p}} ;+500 \mathrm{MWh} / \mathrm{a}\right)$, see Table 4 .

The power consumption of only the ozonation step was calculated with $830 \mathrm{MWh} /$ a covering pumping energy, cooling, ozone generation, ozone dosing and residual ozone destruction. Considering the annual wastewater feed flow of this step $\left(17,975,520 \mathrm{~m}^{3} / \mathrm{a}\right)$ a specific consumption of $0.046 \mathrm{kWh} / \mathrm{m}^{3}$ is expected. This value is expected fort the future operation-mode, corresponding to the lower ranges of values on energy demand technologies for OMP reduction $\left(0.03-0.2 \mathrm{kWh} / \mathrm{m}^{3}\right.$, depending on the specific conditions) on WWTP presented in [48]. The GACF process for the WWTP Mainz was calculated with $410 \mathrm{MWh} / \mathrm{a}$ or $0.023 \mathrm{kWh} / \mathrm{m}^{3}$. In the literature energy consumption for a single operated GACF process is specified to be $0.04 \mathrm{kWh} / \mathrm{m}^{3}$ [48]. Thus, the total energy consumption of $1240 \mathrm{MWh}$ el $/ \mathrm{a}$ of the combined advanced treatment remains within the scope of the energy demand for single operated ozonation.

The power consumption of electrolysis for the base load operation, fed with surplus CHP power generated from surplus biogas, was calculated with $2146 \mathrm{MWh}_{\mathrm{el}} / \mathrm{a}$ and for aFRR services with $2229 \mathrm{MWh} / \mathrm{a}$. Thus, electrolysis produced $2975 \mathrm{MWh}_{\mathrm{H} 2} / \mathrm{a}$ of renewable and storable hydrogen each year, whereby one part will be fed into the natural gas grid and another part will be used for mobility purposes (filling station and public transport). The energy consumption for aFRR services was not considered in the balance in Table 4, because the use of energy from the grid was obligatory and could not be replaced by power generated onsite.

This shows that a large part of expected energy surplus in 2020 could be used for two sustainable processes: green hydrogen and oxygen production as well as OMP removal. Both processes will be coupled and operated for the first time together at one location. If the theoretical remaining surplus of $2861 \mathrm{MWh}_{\mathrm{el}} / \mathrm{a}$ (see Table 4) will be confirmed after implementation of the process, an even more sustainable utilization pathway will be implemented (e.g., additional use in the electrolyzer). 
Table 4. Simplified energetic situation based on the annual average values of the WWTP Mainz before and after the start of the operation of the sludge incineration plant and the implementation of the innovative concept.

\begin{tabular}{|c|c|c|c|c|c|}
\hline $\begin{array}{l}\text { Type of } \\
\text { Indicator }\end{array}$ & Specification & Unit & $\begin{array}{c}\text { Status- } \\
\text { Quo } 2019\end{array}$ & $\begin{array}{l}\text { Expected } \\
\text { in } 2020\end{array}$ & $\begin{array}{r}\text { Including } \\
\text { Concept }\end{array}$ \\
\hline \multirow{4}{*}{$\begin{array}{c}\text { Power } \\
\text { consumption }\end{array}$} & $\begin{array}{c}\text { Total power consumption of } \\
\text { WWTP }\end{array}$ & MWhel/a & -8200 & -7872 & -7872 \\
\hline & $\begin{array}{c}+ \text { power consumption of } \\
\text { advanced treatment }\end{array}$ & MWhel/a & & & -1240 \\
\hline & $\begin{array}{c}+ \text { power consumption of } 20 \% \\
\text { base load operation of } \\
\text { electrolysis }\end{array}$ & MWhel/a & & & -2146 \\
\hline & $\begin{array}{c}\text { (power consumption of } \\
\text { secondary control reserve } \\
\text { aFRR) }{ }^{1}\end{array}$ & MWhel/a & & & $(-2229)$ \\
\hline \multirow{3}{*}{$\begin{array}{l}\text { Biogas } \\
\text { indicators }\end{array}$} & $\begin{array}{l}\text { Produced amount of biogas } \\
\text { onsite }\end{array}$ & $\mathrm{m}^{3} / \mathrm{a}$ & $3,250,000$ & $3,250,000$ & $3,250,000$ \\
\hline & Energy content of biogas ${ }^{2}$ & $\mathrm{MWh}_{\mathrm{CH}} 4 \mathrm{a}$ & 19,825 & 19,825 & 19,825 \\
\hline & Theoretical power of $\mathrm{CHP}$ & MWhel/a & 7633 & 7633 & 7633 \\
\hline \multirow{5}{*}{$\begin{array}{l}\text { Power } \\
\text { production and } \\
\text { purchase }\end{array}$} & Biogas use in CHP & MWhсн4/a & 16,034 & 9468 & 16,964 \\
\hline & $\begin{array}{c}\text { Real power generation of } \\
\text { CHP }\end{array}$ & MWhel/a & +6173 & +3645 & +6531 \\
\hline & PV power generation & MWhel/a & +227 & +227 & +727 \\
\hline & $\begin{array}{l}\text { Purchased power from public } \\
\text { electricity network }\end{array}$ & MWhel/a & +1800 & 0 & 0 \\
\hline & net Power from TVM ${ }^{3}$ & MWhel/a & 0 & +4000 & +4000 \\
\hline \multirow{2}{*}{ Surplus Power } & $\begin{array}{l}\text { Corresponding surplus biogas } \\
\text { (flared in the status quo) }\end{array}$ & MWhсH4/a & +3791 & $+10,357$ & +2861 \\
\hline & $\begin{array}{l}\text { Theoretical resulting power } \\
\text { surplus on site }\end{array}$ & MWhel/a & +1460 & +3988 & +1102 \\
\hline $\begin{array}{l}\text { Hydrogen } \\
\text { indicator }\end{array}$ & $\begin{array}{l}\text { Resulting hydrogen } \\
\text { production of electrolysis }\end{array}$ & MWhн2/a & & & +2975 \\
\hline
\end{tabular}

${ }^{1}$ Not included in the balance, due to linkage to external energy market situation; ${ }^{2}$ calculated on the basis of a heating value of biogas of $6,1 \mathrm{kWh} / \mathrm{m}^{3} ;{ }^{3}$ electrical surplus power of TVM after electrical supply of internal TVM-processes (including dewatering of sludge).

\section{Environmental Effects}

The implementation of the proposed project will lead to significant environmental improvements:

- Reduction of OMP discharges,

- Reduction of standard parameters discharges (total phosphorus $\left(\mathrm{P}_{\text {tot }}\right)$, total suspended solids (TSS) and chemical oxygen demand (COD)),

- Supporting the energy transition and,

- Multilevel reduction of $\mathrm{CO}_{2}$ emissions.

\subsection{Environmental Improvements through Improved Water Protection}

One central environmental improvement will be the reduction of emissions of OMP. Table 5 presents an estimation of the expected reduction of emissions from substances included in the following substance groups and fields of application:

- Drugs,

- X-ray contrast agent,

- Household chemicals,

- Personal care and,

- Others. 
Table 5. Assessment of the environmental relief through implementation of the advanced treatment for OMP removal at WWTP Mainz (elimination values based on experiences from full-scale WWTPs with the single stage OMP treatment).

\begin{tabular}{|c|c|c|c|c|c|c|c|c|}
\hline Substance & $\begin{array}{l}\text { Substance Group/Field } \\
\text { of Application }\end{array}$ & Specification & $\begin{array}{c}\text { Elimination by } \\
\text { Advanced } \\
\text { Treatment }[\%]^{1}\end{array}$ & $\begin{array}{c}\text { Average Effluent } \\
\text { Concentration } \\
\mathrm{n}=5[\mu \mathrm{g} / \mathrm{L}]\end{array}$ & $\begin{array}{c}\text { Dry Weather } \\
\text { Runoff } 2017 \\
{\left[\text { Mio } \mathrm{m}^{3} / \mathrm{a}\right]} \\
\end{array}$ & $\begin{array}{c}\text { Calculated Emission } \\
\text { Load Status Quo } \\
(\mathrm{kg} / \mathrm{a})\end{array}$ & $\begin{array}{l}\text { Reduction of Emission } \\
\text { Load in (kg/a) with 4th } \\
\text { Treatment Stage } \\
\end{array}$ & $\operatorname{CQS}\left([\mu \mathrm{g} / \mathrm{L})^{4}\right.$ \\
\hline Carbamazepine & \multirow{4}{*}{ drug } & anti-epileptic & 90 & 0.45 & 15.59 & 7.04 & 6.3 & 2.00 \\
\hline Diclofenac & & anti-inflammatory & 90 & 2.34 & 15.59 & 36.47 & 32.8 & 0.05 \\
\hline Ibuprofen & & anti-inflammatory & 80 & 0.22 & 15.59 & 3.42 & 2.7 & 0.11 \\
\hline Sulfamethoxazole & & antibiotics & 90 & 0.29 & 15.59 & 4.46 & 4.0 & 0.60 \\
\hline Amidotrizoic acid & \multirow{2}{*}{ X-ray contrast agent } & X-ray contrast agent & 10 & 2.76 & 15.59 & 43.02 & 4.3 & -5 \\
\hline Iomeprol & & X-ray contrast agent & 50 & 75.80 & 15.59 & $1,181.41$ & 590.7 & - \\
\hline Perfluoroctane sulfonic acid (PFOS) & \multirow[b]{2}{*}{ household chemicals } & fluorosurfactant & 50 & $0.046^{2}$ & 15.59 & 0.72 & 0.7 & 0.022 \\
\hline Perfluorooctance acid (PFOA) & & fluorosurfactant & 50 & $0.010^{2}$ & 15.59 & 0.14 & 0.1 & - \\
\hline НHCB & \multirow{2}{*}{ personal care } & synthetic fragrances & 90 & 0.54 & 15.59 & 8.48 & 7.6 & - \\
\hline Triclosan & & disinfectant & 80 & $0.046^{3}$ & 15.59 & 0.72 & 0.5 & 0.11 \\
\hline EDTA & others & complexing agent & 10 & 96.00 & 15.59 & 1496.24 & 149.6 & 2200 \\
\hline
\end{tabular}

${ }^{1}$ Elimination quantity is assumed to be conservative and is based on the elimination of other studies such as [5,49,50]; ${ }^{2}$ based on 2 effluent samples; ${ }^{3}$ based on 1 effluent sample; ${ }^{4}$ CQS values taken from $[8]]^{5}$ no CQS value available. 
Comprehensive experiences from full scale plants for OMP elimination with a combined ozone and GAC process do not exist yet. Thus, the elimination percentages listed in Table 5 are expected to be the minimum eliminations, derived from experiences with one-step OMP treatment plants. It is assumed that these values should normally be exceeded in the context of large-scale implementation in Mainz, especially due to the combination of ozonation with additional GACF. Other studies are proving theses expected eliminations $[5,49,50]$. Although the values in Table 5 are calculated at the safe side, they show a significant reduction in emissions for a large number of substances, especially for substances occurring in critical concentrations in the Rhine River, such as DCF.

Considering these key substances, a significant reduction of the effluent load can be expected. Table 5 points out, too, that the elimination varies strongly between 10 and $90 \%$, depending on the substance. For some substances CQS are available. For most of those a significant reduction can be achieved, e.g., for the drug substances carbamazepine, diclofenac and ibuprofen. For further OMP, e.g., the origin of household and personal care products, relevant reductions are expected to be between 50 and $80 \%$. Although the complexing agent EDTA was only reduced in the order of $10 \%$, its concentration was far below the proposed CQS value of $2200 \mu \mathrm{g} / \mathrm{L}$ [8].

A downstream installed filter (GACF) step will have positive aspects on the elimination of conventional wastewater constituents, too. The efficient reduction of $\mathrm{P}_{\text {tot }}$ and TSS of municipal wastewater effluent by GACF could be shown in [51] with a reduction of up to $85 \%$ for $\mathrm{P}_{\text {tot }}$ and $75 \%$ for TSS. Additionally, COD concentrations can be reduced significantly by a filtration step [52]. Therefore, due to the combined implementation of ozonation and GACF a reduction of the parameters COD, $P_{\text {tot }}$ and TSS is also expected.

\subsection{Environmental Improvements through Contributions to the Energy Transition}

The implementation of the proposed concept will demonstrate that the transition of the energy system is possible and sector coupling as well as hydrogen play a decisive role. Currently some major problems regarding the energy sector are still unsolved:

- How can renewable power be stored at a large scale?

- How do we manage a heat supply system based on renewable energies?

- How can we realize a proper defossilization in the transport and industry sectors?

- How can we offer system services for the power grid based on RE?

Electrolysis provides a key answer to these questions. On the one hand, electrolysis enables (green) electricity to be converted into renewable gas and stored in the gas grid over a longer period. The hydrogen can be used in a natural gas-wind gas mixture for cooking and heating. Converted to methane [53], it could even completely replace fossil natural gas. On the other hand, there are diverse applications for hydrogen in the transport and industry sector.

In addition to the innovative provision of oxygen for ozonation, the operation of the electrolyzer enhances the energy transition and reduces the environmental pollution in Mainz:

- With the amount of hydrogen fed into the NGI at the WWTP, 250 apartments (each $50 \mathrm{~m}^{2}$ living space) could be supplied with renewable heat. In this case, the use of green hydrogen reduces greenhouse gas emissions by $83 \%$ compared to the use of fossil natural gas. Furthermore, hydrogen enables long-term storage of electricity.

- Supplementary to the feed into the NGI, the hydrogen produced at the WWTP can supply four fuel cell buses, saving around 190,000 L of diesel per year. By using green hydrogen in fuel cell buses, greenhouse gas emissions are reduced by $89 \%$ compared to a diesel bus.

- By offering secondary control reserve (aFRR), the electrolyzer contributes to the stability of the local power grid. Thus, conventional and $\mathrm{CO}_{2}$ producing power generation plants are replaced from the national balancing market.

- By expanding the PV capacity on the WWTP site, less biogas is required in the CHP unit and is saved for other situations. Thereby the overall greenhouse gas balance of the WWTP is improving. 


\subsection{Environmental Relief through $\mathrm{CO}_{2}$ Reductions}

With an assumed feed-in limit for hydrogen of 2 vol.-\% of the gas flux, 1240 MWh of hydrogen could be fed into the NGI annually, displacing natural gas and thus avoiding around $200 \mathrm{tCO}_{2} \mathrm{e} / \mathrm{a}$ (natural gas from steam reforming causes around $202 \mathrm{gCO} 2 \mathrm{e} / \mathrm{kWh}$ [54]. The greenhouse gas emissions of the produced hydrogen at the WWTP amount to around $34 \mathrm{gCO} 2 \mathrm{e} / \mathrm{kWh} \mathrm{H}_{2}$, considering the electricity supply (renewable electricity, CHP unit based on local biogas and local PV plants), the production of the electrolyzer, the compression of hydrogen and an efficiency of the electrolyzer of $68 \%$ ). By using the remaining $1735 \mathrm{MWh}$ of hydrogen in fuel cell buses in public transport, another approximately $500 \mathrm{tCO}_{2} \mathrm{e} / \mathrm{a}$ (calculated greenhouse gas emission for the diesel bus: $166 \mathrm{kgCO}_{2} \mathrm{e} / 100 \mathrm{~km}$ and for the fuel cell bus: $17 \mathrm{kgCO}_{2} \mathrm{e} / 100 \mathrm{~km}$. With a consumption of $13 \mathrm{kgH}_{2} / 100 \mathrm{~km} \mathrm{[55],} \mathrm{four} \mathrm{fuel} \mathrm{cell} \mathrm{buses} \mathrm{driving}$ $220 \mathrm{~km}$ daily can be used) could be saved in comparison to diesel buses. Additionally, greenhouse gas emissions are avoided through the replacement of conventional power plants for providing control reserve by the electrolyzer. The avoided greenhouse gas emissions through an alternative oxygen supply via air separation should be considered, too. In order to generate one kilogram of oxygen via air separation, approximately $0.3 \mathrm{kWh}$ of electricity is needed [56]. Assuming a supply of grey electricity, the conventional oxygen production would cause approximately $70 \mathrm{tCO}_{2} \mathrm{e} / \mathrm{a}$ (the amount of oxygen produced: $600 \mathrm{t} / \mathrm{a} ; 400 \mathrm{gCO}_{2} \mathrm{e} / \mathrm{kWh}$ grey electricity (data set: EL-KW-Park-DE-2020) [57]) [22,37]. Beyond that, by using the local biogas from the WWTP in the CHP unit to provide electricity for the advanced treatment step, a further $500 \mathrm{tCO}_{2} \mathrm{e} / \mathrm{a}$ (electricity consumption 4th cleaning stage: $1.250 \mathrm{MWh} / \mathrm{a}$ and greenhouse gas emissions: $400 \mathrm{gCO}_{2} \mathrm{e} / \mathrm{kWh}$ grey electricity (data set: EL-KW-Park-DE-2020) [57] 2,3 $\mathrm{gCO}_{2} \mathrm{e} / \mathrm{kWh}$ for electricity from sewer gas (data set: Klärgas-BHKW-GM 200-OxKat-2020/en [57]) can be reduced in comparison to the use of grey electricity from the grid.

Overall, as shown in Figure 7, this results in savings of $1279 \mathrm{tCO}_{2} \mathrm{e} / \mathrm{a}$. This corresponds to the annual $\mathrm{CO}_{2}$ storage capacity of around 128 ha of forest ( 1 ha of forest binds around $10+\mathrm{CO}_{2}$ yearly [58]).

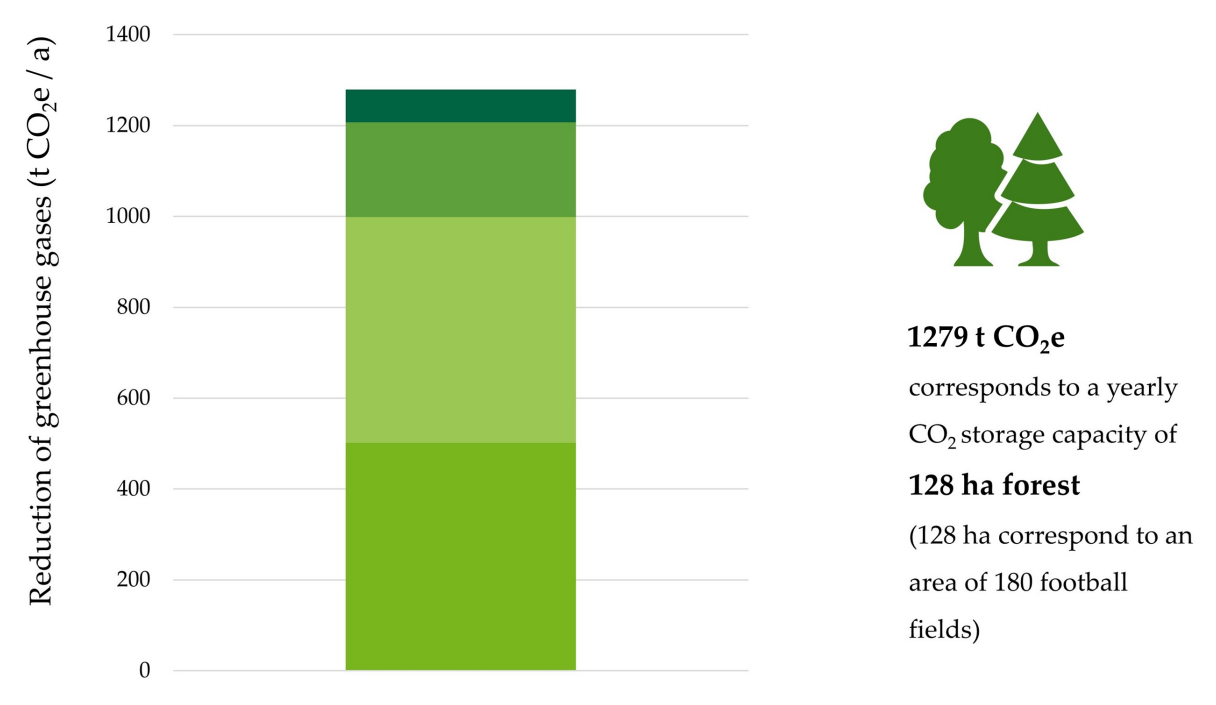

घublic transport $\square$ Renewable operation of advanced treatment $\quad$ Heat sector $\quad$ Oxygen production

Figure 7. Annual savings in greenhouse gas emissions through the use of electrolysis after implementation of the project in comparison to conventional power use [41]. 


\section{Techno-Economical Aspects}

As shown in Section 2.3 the launch of TVM will change the energy situation at the WWTP Mainz fundamentally: the plant will have a significant amount of surplus of energy. The common renewable power feed of CHP electricity into the public grid is uneconomical for the operator. It would be a losing deal and at the same time it would not be sustainable, due to the loss of flexibility characters of the biogas. These were central aspects for the operator to look for alternative options and a new and more holistic business case.

For the economic evaluation the operation of the electrolyzer and the oxygen storage unit as the central coupling element are considered. The advanced treatment step for OMP removal is neglected, because it is part of the wastewater treatment and will be financed by charges.

If hydrogen is fed directly into the gas grid, hydrogen equates with biogas. For biogas, a market with a higher willingness to pay already exists in Germany. The price for $1 \mathrm{kWh}$ of biogas is actually around $€ 0.06$ and varies depending on the quality of the biogas. Depending on the full load hours, the production costs for hydrogen are about $0.15 € / \mathrm{kWh}$, with an EEG surcharge and network charges up to $0.38 € / \mathrm{kWh}$ [59]. Main driver for the economy of PtG-projects are the operating costs, among them the electricity costs are dominating. Due to the expansion and integration of the local renewable electricity generation in the energy concept of the electrolyzer on the WWTP, the economic advantages of self-supply (mainly reduction of the EEG surcharge) are helping to improve the economic situation. Nonetheless, due to the high hydrogen production costs, the electrolyzer can only be operated economically if the consumer is willing to pay more than the above mentioned $0.06 € / \mathrm{kWh}$ or if appropriate subsidies are given. The energy supplier Greenpeace Energy involved in the project at WWTP Mainz offers a special gas tariff to encourage innovative and energy-transition-supporting concepts with power-to-gas technologies. This tariff includes a premium for each kilowatt-hour of consumed gas. Through this support, the supplier is able to build its own power-to-gas plants and to buy green hydrogen from plants operated by third parties in an energy transition supporting manner [60]. The higher willingness to pay enables the economical operation of these power-to-gas plants and helps to foster the technology.

To avoid blow off situations of parts of the $\mathrm{O}_{2}$ production due to the flexible operation (in the frame of aFRR calls) of the electrolyzer on the one hand and to provide ozonation as high as possible with $\mathrm{O}_{2}$ as the co-product from the electrolyzer, on the other hand, an $\mathrm{O}_{2}$-storage will be installed (see Section 4.4). This will reduce the additional liquid oxygen demand significantly. To guarantee the permanent supply with $\mathrm{O}_{2}$ of the ozone generator a liquid oxygen tank will still be available. By using an oxygen storage tank, the use of external liquid oxygen can be minimized, thus reducing costs in this field. Table 6 shows that by using $\mathrm{O}_{2}$ with an origin from control energy calls (aFRR), the coverage gap can be closed and 17,320 €/a for liquid oxygen can be avoided, when assuming costs for liquid $\mathrm{O}_{2}$ of $0.10 € / \mathrm{kg}$.

Table 6. Oxygen demand and avoided costs depending on the "source" of oxygen.

\begin{tabular}{|c|c|c|c|c|}
\hline & Oxygen & Unit & Avoided Costs for Liquid $\mathrm{O}_{2}{ }^{1}$ & Unit \\
\hline $\begin{array}{l}\text { Oxygen demand for } \\
\text { ozone production: }\end{array}$ & 465,206 & $\mathrm{kgO}_{2} / \mathrm{a}$ & & \\
\hline $\begin{array}{l}\text { Oxygen production by } 20 \% \text {-load } \\
\text { of electrolyzer: }\end{array}$ & 292,000 & $\mathrm{kgO}_{2} / \mathrm{a}$ & 29,200 & $€ / a$ \\
\hline Resulting coverage gap: & 173,206 & $\mathrm{kgO}_{2} / \mathrm{a}$ & & \\
\hline $\begin{array}{l}\text { Oxygen production by control } \\
\text { energy calls (aFRR): }\end{array}$ & 307,569 & $\mathrm{kgO}_{2} / \mathrm{a}$ & & \\
\hline Usable to close coverage gap: & 173,206 & $\mathrm{kgO}_{2} / \mathrm{a}$ & 17,320 & $€ / \mathrm{a}$ \\
\hline
\end{tabular}


In total $47,000 € /$ a of costs for liquid oxygen can be saved by utilizing the co-product of electrolysis. These yearly savings can be used to calculate the amortization of the oxygen storage including the pre-treatment. The range of costs for the $\mathrm{O}_{2}$ treatment and storage is indicated for each relevant component in Table 7 based on [37]. In the best case the components amortize in 10.5 years, in the worst case in 14.3 years. This shows the medium-term economic feasibility of this central coupling component of both processes of the presented concept.

Table 7. Ranges of gross costs of the components for oxygen storage and treatment.

\begin{tabular}{ccc}
\hline & Costs & Unit \\
\hline $\mathrm{O}_{2}$ dryer & $180,000-264,000$ & $€$ \\
Compressor & $80,000-131,000$ & $€$ \\
$\mathrm{O}_{2}$ storage $\left(100 \mathrm{~m}^{3}\right)$ & $170,000-220,000$ & $€$ \\
Pressure reduction & 66,000 & $€$ \\
\hline Set gross costs & $(496,000)-681,000$ & $€$ \\
\hline
\end{tabular}

\section{Discussion and Outlook}

Hydrogen and thus electrolysis are a relevant part of a successful progressing energy transition as shown in different studies [3,18,61-63]. In early 2019, 95 projects with electrolysis and methanation technologies were active worldwide, most projects were located in Germany, Denmark, the United States and Canada [64]. Actually, the framework conditions, respectively, the regulations in Europe, are not perfectly suited to PtG and are still not promoting a faster rollout. Today most hydrogen projects are pilot projects with lifetimes up to 3 years, depending on funding to cover operating costs or on additional willingness-to-pay of consumers [64]. To improve economic efficiency, it would be beneficial to use all products of the plant: hydrogen or methane, heat and oxygen, but only few projects worldwide address this topic [64]. In the long term, an exponential global increase of PtG projects is expected, which will lead to an enormous reduction of the investment costs from today's $1.300 € / \mathrm{kW}$ to about $500 € / \mathrm{kW}[59,64]$. However, in respect to the regulation in Europe, the main driver for the economy of $\mathrm{PtG}$ projects is the operating costs, among them particularly the electricity costs. In Germany mainly regulation about the electricity taxes and levies are hindering the economy of an electrolyzer project. According to the EEG 2017, every natural and legal person who consumes electricity is a final consumer. Since an electrolyzer fulfills the criteria for electricity storage or the energy converter, it is considered as a final consumer and is therefore obliged to pay all electricity levies and taxes [65]. Reductions and exemptions only arise in very few cases. Today these costs for state taxes and levies can amount to up to $160 € / \mathrm{MWh}_{\mathrm{el}}$ [66]. Solely out of the EEG tax results an amount of $103.94 € / \mathrm{MWh}_{\mathrm{H} 2}(67.56 € / \mathrm{MWh}$ divided by the efficiency of the electrolyzer of $65 \%)$ [67]. Furthermore, there is no European regulation for the certification of hydrogen and for the feed into the European gas grid as well as the cross-border trade of hydrogen.

As described in Section 4 the mode of operation and the power supply mainly influence whether an electrolysis operation is energy-efficient and/or supports the energy transition. This should be considered when designing further funding programs and new regulations for the electrolyzer.

The implementation of an advanced treatment step for the reduction of OMP at WWTP is already regulated in Switzerland and is discussed in many other countries to improve the surface water quality. This additional treatment step will lead to increasing energy consumption (e.g., operation of the new process, oxygen production and AC production/regeneration) onsite or offsite. Plant operators have to decide about the sustainability of this new step. 
The combination of both processes offers the opportunity to use synergy effects:

- Increasing the efficiency of the electrolyzer by using the co-products $\mathrm{O}_{2}$ (for ozonation) and heat (e.g., in the digester of WWTP);

- Economizing the purchase of liquid $\mathrm{O}_{2}$;

- Enhancing the energy transition by the expansion and integration of the local renewable energy generation in the energy system of the power-to-gas plants and by optimizing the overall energy management at the WWTP site.

In particular with a view to the mandatory progress made in the energy transition (in the electricity, heating and mobility sectors) in combination with possible nationwide obligations on WWTP to specifically eliminate OMP, the proposed process combination has a model character and might be transferable to numerous other WWTP locations. The economic conditions are likely to improve significantly in the near future, but will not be available at the current time. Therefore, funds are required for an economical operation.

Electrolysis technology is the key technology to defossilize the energy and material cycles and is therefore imperative to achieve the climate protection goals [3]. This also significantly increases the possibility of transferring the concept to other WWTPs.

The energetic environment and boundary conditions are an important aspect of each electrolyzer project. The Mainz site showed rather unfavorable boundary conditions due to the local grid situation. However, despite (currently) missing surplus energy situations, an ecological and energy-transition-supporting operating concept could be developed. Due to the feasibility at such an unfavorable location, transferability is ultimately possible to many other locations. In Germany, this affects 100 large WWTPs with anaerobic sludge stabilization, without an advanced treatment step for the reduction of OMP, and they are still emitting considerable loads of OMP into waters.

The combination of power-to-gas technology and advanced wastewater treatment and the selected process combination for the OMP treatment in this size will be implemented for the first time in full scale on a municipal WWTP and underlines the innovative character of the entire project. With possible stricter requirements for wastewater treatment in the future and an advancing energy transition worldwide, the transferability of this combination of processes has great potential for WWTP in and out of Germany. Therefore, further investigations are needed to develop additional business cases as well as to assess a transferability of the present study results.

Supplementary Materials: The following are available online at http://www.mdpi.com/1996-1073/13/14/3599/s1, Supplementary Materials Data S1: Results of Analysis of Effluent and Influent Samples.

Author Contributions: Conceptualization, O.G., M.S.; methodology, O.G., M.S.; formal analysis, M.S. and O.G.; investigation, M.S., O.G., S.K., K.K., E.P.; data curation, O.G., M.S., S.K., K.K., E.P.; writing-original draft preparation, O.G., M.S., K.K., E.P.; writing-review and editing, M.S., O.G., H.S., K.K., E.P.; visualization, O.G., K.K.; supervision, H.S.; All authors have read and agreed to the published version of the manuscript.

Funding: This research was funded by Wirtschaftsbetrieb Mainz AöR (WBM) of the city of Mainz, Germany.

Acknowledgments: Special thanks to Herbert Hochgürtel (WBM) and his team for helpful suggestions and discussions during the implementation of the feasibility studies as well to the Mainzer Stadtwerke for their support concerning questions around the local power and gas grid. Further, the authors would like to thank the German Federal Ministry for the Environment, Nature Conservation, Building and Nuclear Safety for funding the upcoming realization and the further research on this project, as part of the Environmental Innovation Program, as well as to the Ministry of the Environment, Energy, Food and Forests of the German regional state of Rhineland-Palatinate for its support.

Conflicts of Interest: The authors declare no conflict of interest. 


\section{Abbreviations}

AA-QS annual average-quality standard AA-QS, chronical quality standard

AC active carbon

automatic frequency restoration reserve-automatic activated reserve as system services for the power grid (secondary control)

Background: the German transmission system operators (TSOs) have to maintain the balance between electricity generation and consumption within the control areas at all times. Therefore, the TSOs need different types of control reserve, which can be divided into three groups:

- $\quad$ Frequency containment reserve (FCR, also called the primary control reserve):

Automatic and complete activation of the primary control reserve within

aFRR 30 seconds

- $\quad$ Frequency restoration reserve with automatic activation (aFRR, also called the secondary control reserve)

complete activation within five minutes (at most)

- $\quad$ Frequency restoration reserve with manual activation (mFRR):

Complete activation within fifteen minutes

[68]

$\mathrm{CO}_{2} \mathrm{e} \quad$ Equivalent carbon dioxide

COD chemical oxygen demand

chronical quality standard or annual average-quality standard (AA-QS): “Chronic quality standards are recommended for water quality monitoring. They can be used for assessing

CQS pollution over an extended time period. For the continuous input of micropollutants from treated effluents, the chronic quality standard is particularly relevant and helps to protect the organisms against the consequences of long-term pollution." [8]

DOC dissolved organic carbon

$\eta_{\mathrm{el}} \quad$ electrical efficiency

GAC granulated active carbon

GACF granulated active carbon filter

OMP organic micropollutant

$\mathrm{MW}_{\mathrm{el}} \quad$ Megawatt electrical power

NGI natural gas infrastructure

PE population equivalent

$\mathrm{PE}_{120} \quad \mathrm{PE}_{120}$ is population equivalent, assuming $120 \mathrm{~g}$ of chemical oxygen demand (COD) per PE and per day

$P_{\text {tot }} \quad$ total phosphorus

PtG Power to Gas

PV photovoltaic energy generation

$\mathrm{Q}_{\mathrm{d}, \mathrm{h}, \max } \quad$ Maximum hourly wastewater flow during dry weather

$\mathrm{RE} \quad$ renewable energies

TOC total organic carbon

TSS total suspended solids

TVM Thermische Verwertung Mainz-sludge incineration plant

WWTP wastewater treatment plant

\section{Appendix A. Oxygen and Ozone-Effects of different $\mathrm{NO}_{2}-\mathrm{N}$ concentrations}

The oxygen demand for ozonation depends on different parameters of the treated water. For the determination of the oxygen demand for the planned ozonation at the WWTP Mainz the potential influent of the planned ozonation step (which is the actual effluent of the WTP) was analyzed concerning the following relevant parameters with average concentrations of: 
- $\quad \mathrm{DOC}=12.9 \mathrm{mg} / \mathrm{L} ;$

- Nitrite-Nitrogen $\left(\mathrm{NO}_{2}-\mathrm{N}\right)=0.47 \mathrm{mg} / \mathrm{L}(25 \%$ percentile $=0.10 \mathrm{mg} / \mathrm{L} ; 85 \%$ percentile $=1.00 \mathrm{mg} / \mathrm{L})$.

Especially elevated nitrite-nitrogen $\left(\mathrm{NO}_{2}-\mathrm{N}\right)$ concentrations can cause an additional demand for ozone. The oxidation of $1 \mathrm{~g} \mathrm{NO}_{2}-\mathrm{N}$ consumes $3.43 \mathrm{~g}$ of ozone. The operator and authors expect that the nitrite concentration will be reduced with the operation of a deammonification step in 2020. To show the sensitivity of this parameter, two further $\mathrm{NO}_{2}-\mathrm{N}$ concentrations were used to quantify the influence on ozone demand.

- Reduction of $\mathrm{NO}_{2}-\mathrm{N}$ concentration in the feed by $50 \%$ to $0.235 \mathrm{mg} / \mathrm{L}$;

- Reduction of $\mathrm{NO}_{2}-\mathrm{N}$ concentration in the feed by $100 \%$ to $0.0 \mathrm{mg} / \mathrm{L}$.

If ozonation is operated without a subsequent GACF, usually ozone concentrations are applied in the range of $0.6-0.9 \mathrm{gO}_{3} / \mathrm{gDOC}$ [69]. Based on the own experiences of the working group of this study with combined ozone-GACF technology at the experimental scale [70] the following ozone doses were chosen:

- $\quad$ Maximum concentration: $0.4 \mathrm{gO}_{3} / \mathrm{gDOC}$;

- Average concentration: $0.2 \mathrm{gO}_{3} / \mathrm{gDOC}$.

The ozone demand resulting from maximum and average flows combined with two different dosing rates and the effect of changing the nitrite concentration is illustrated in the Table A1. The produced gas from the ozone generator contains a mass fraction of $10 \%$ ozone (out of $10 \mathrm{kgO}_{2}, 1 \mathrm{kgO}_{3}$ can be generated).

Table A1. Impact of the reduced nitrite-concentration on oxygen and ozone demand in the advanced treatment step for OMP reduction.

\begin{tabular}{|c|c|c|c|c|c|}
\hline & & Status-Quo & $\begin{array}{c}-50 \% \\
\mathrm{NO}_{2}-\mathrm{N}\end{array}$ & $\begin{array}{l}-100 \% \\
\mathrm{NO}_{2}-\mathrm{N}\end{array}$ & Unit \\
\hline \multicolumn{6}{|l|}{ necessary ozone dose } \\
\hline \multirow{4}{*}{ specific ozone dose with regard to DOC } & maximum & 800.0 & 800.0 & 800.0 & $\mathrm{~L} / \mathrm{s}$ \\
\hline & average & 570.0 & 570.0 & 570.0 & $\mathrm{~L} / \mathrm{s}$ \\
\hline & maximum & 0.4 & 0.4 & 0.4 & $\mathrm{~g} \mathrm{O}_{3} / \mathrm{g} \mathrm{DOC}$ \\
\hline & average & 0.2 & 0.2 & 0.2 & $\mathrm{~g} \mathrm{O}_{3} / \mathrm{g}$ DOC \\
\hline \multirow{2}{*}{$\begin{array}{l}\text { average feed concentration of DOC } \\
\text { specific ozone dose with regard to } \\
\text { nitrite-nitrogen }\end{array}$} & & 12.94 & 12.94 & 12.94 & mg DOC/L \\
\hline & & 3.43 & 3.43 & 3.43 & $\mathrm{~g} \mathrm{O}_{3} / \mathrm{g} \mathrm{N}$ \\
\hline average feed concentration of nitrite & & 0.47 & 0.24 & 0.00 & $\mathrm{mg} \mathrm{NO}-\mathrm{N} / \mathrm{L}$ \\
\hline \multirow{2}{*}{ necessary ozone dose } & maximum & 6.79 & 5.98 & 5.18 & $\mathrm{mg} \mathrm{O}_{3} / \mathrm{L}$ \\
\hline & average & 4.20 & 3.39 & 2.59 & $\mathrm{mg} \mathrm{O}_{3} / \mathrm{L}$ \\
\hline \multicolumn{6}{|l|}{ Oxygen demand } \\
\hline \multirow{6}{*}{$\begin{array}{c}\text { spec. oxygen demand for ozone production } \\
\text { necessary oxygen }\end{array}$} & & 10.0 & 10.0 & 10.0 & $\mathrm{mgO}_{2} / \mathrm{mgO}_{3}$ \\
\hline & maximum & 195.5 & 172.3 & 149.1 & $\mathrm{~kg} \mathrm{O}_{2} / \mathrm{h}$ \\
\hline & & 4692 & 4135 & 3578 & $\mathrm{~kg} \mathrm{O}_{2} / \mathrm{d}$ \\
\hline & average & 86.2 & 69.7 & 53.1 & $\mathrm{~kg} \mathrm{O}_{2} / \mathrm{h}$ \\
\hline & & 2068.5 & 1671.5 & 1274.5 & $\mathrm{~kg} \mathrm{O}_{2} / \mathrm{d}$ \\
\hline & & 754,989 & 610,098 & 465,206 & $\mathrm{~kg} \mathrm{O}_{2} / \mathrm{a}$ \\
\hline \multicolumn{6}{|l|}{ Ozone demand } \\
\hline \multirow{2}{*}{ Ozone demand } & maximum & 19.55 & 17.23 & 14.91 & $\mathrm{~kg} \mathrm{O}_{3} / \mathrm{h}$ \\
\hline & average & 8.62 & 6.96 & 5.31 & $\mathrm{~kg} \mathrm{O}_{3} / \mathrm{h}$ \\
\hline
\end{tabular}

Table A2 illustrates the range of a reduction of the oxygen demand due to a reduction of the nitrite concentration in the feed up to $38 \%$ compared to the status quo. Compared to the status quo the oxygen demand would be decreased by $290,000 \mathrm{~kg} / \mathrm{a}$. The coverage of oxygen demand by the electrolyzer is illustrated for the different nitrite-scenarios in the following table. Considering a complete nitrite reduction, the $1.25 \mathrm{MW}$ electrolyzer would be able to cover approximately $63 \%$ of the yearly oxygen demand by its base load power of $20 \%$. For the design of $\mathrm{O}_{2}$ storage (Section 4.4 ) a zero-nitrite concentration was assumed, which has to be specified in the implementation planning. 
Table A2. Oxygen demand and coverage gaps depending on the nitrite concentration in the feed of the ozonation step.

\begin{tabular}{|c|c|c|c|c|c|c|c|}
\hline & \multicolumn{7}{|c|}{$\begin{array}{c}\text { Change in Nitrite-Nitrogen } \\
\text { Concentration }\end{array}$} \\
\hline & & & Status-Quo & $\begin{array}{c}-50 \% \\
\mathrm{NO}_{2}-\mathrm{N}\end{array}$ & $\begin{array}{l}-100 \% \\
\mathrm{NO}_{2}-\mathrm{N}\end{array}$ & Pos & \\
\hline & Oxygen demand & $(\mathrm{kg} / \mathrm{a})$ & 754,990 & 610,098 & 465,206 & P1 & \\
\hline & $\begin{array}{l}\text { Oxygen reduction compared to } \\
\text { status-quo }\end{array}$ & $(\mathrm{kg} / \mathrm{a})$ & 0 & 144,892 & 289,783 & P2 & \\
\hline \multirow{2}{*}{$\begin{array}{l}\text { Use of oxygen from } 20 \% \\
\text { base-load }\end{array}$} & $\begin{array}{l}\text { Oxygen from electrolysis ( } 20 \% \\
\text { base load) }\end{array}$ & $(\mathrm{kg} / \mathrm{a})$ & 292,000 & 292,000 & 292,000 & P3 & \\
\hline & Oxygen coverage gap & $(\mathrm{kg} / \mathrm{a})$ & 462,990 & 318,098 & 173,206 & P4 & $=\mathrm{P} 1-\mathrm{P} 3$ \\
\hline \multirow{5}{*}{$\begin{array}{l}\text { Use of total oxygen } \\
\text { (including aFRR-calls of the } \\
\text { electrolyzer }\end{array}$} & $\begin{array}{l}\text { Oxygen from electrolysis } \\
\text { (from aFRR) }\end{array}$ & $(\mathrm{kg} / \mathrm{a})$ & 307,569 & 307,569 & 307,569 & P5 & \\
\hline & \multirow{2}{*}{ thereof need in ozonation } & \multirow{2}{*}{$(\mathrm{kg} / \mathrm{a})$} & \multirow{2}{*}{307,569} & \multirow{2}{*}{307,569} & \multirow{2}{*}{173,206} & \multirow{2}{*}{ P6 } & $=\mathrm{P} 5($ if $\mathrm{P} 5<\mathrm{P} 4)$ \\
\hline & & & & & & & $=\mathrm{P} 4($ if $\mathrm{P} 5>\mathrm{P} 4)$ \\
\hline & remaining oxygen coverage gap & $(\mathrm{kg} / \mathrm{a})$ & 155,421 & 10,529 & 0 & P7 & $=\mathrm{P} 4-\mathrm{P} 6$ \\
\hline & $\begin{array}{l}\text { thereof remaining } \\
\text { oxygen surplus }\end{array}$ & $(\mathrm{kg} / \mathrm{a})$ & 0 & 0 & 134,363 & P8 & $=\mathrm{P} 5-\mathrm{P} 6$ \\
\hline
\end{tabular}

\section{References}

1. United Nations. The Paris Agreement. Available online: https://unfccc.int/process-and-meetings/the-parisagreement/the-paris-agreement (accessed on 22 April 2020).

2. Quaschning, V. Klimaschutz oder Deichbau? Warum wir nicht erst 2038 aus der Kohleverstromung Aussteigen Können. Vortrag beim Energietag Rheinland-Pfalz 2019; Energietag Rheinland-Pfalz. TSB Transferstelle Bingen: Bingen, Germany, 2019.

3. Sterner, M. Power-to-X and Sector Coupling: Setting the Right Legislative Framework for 230 Technology Pathways to Meet the Paris Climate Goals in Germany; IRES International Renewable Energy Storage: Düsseldorf, Germany, 2019.

4. Jose, J.; Sandra Pinto, J.; Kotian, B.; Mathew Thomas, A.; Narayana Charyulu, R. Comparison of the regulatory outline of ecopharmacovigilance of pharmaceuticals in Europe, USA, Japan and Australia. Sci. Total Environ. 2020, 709, 134815. [CrossRef] [PubMed]

5. Penru, Y.; Guillon, A.; Esperanza, M.; Martin, S.; Baig, S.; Miege, C.; Daval, A.; Cretollier, C.; Masson, M.; Coquery, M.; et al. Ozonation: Elimination des Micropolluants / Elimination von Mikroverunreinigungen durch Ozonung. Aqua Gas 2017, 97, 42-49.

6. Peake, B.M.; Braund, R.; Tong, A.Y.C.; Tremblay, L.A. Regulatory Practices to Control the Discharge of Pharmaceuticals into the Environment. The Life-Cycle of Pharmaceuticals in the Environment; Elsevier: Amsterdam, The Netherlands, 2016; pp. 203-228. ISBN 9781907568251.

7. Miarov, O.; Tal, A.; Avisar, D. A critical evaluation of comparative regulatory strategies for monitoring pharmaceuticals in recycled wastewater. J. Environ. Manag. 2020, 254, 109794. [CrossRef]

8. oekotoxzentrum. Proposals for Acute and Chronic Quality Standards. Available online: https://www.ecotoxcentre.ch/expert-service/quality-standards/proposals-for-acute-and-chronic-qualitystandards/?_ga=2.53865448.1586158361.1587446765-2105293851.1585640125 (accessed on 21 April 2020).

9. Gerbersdorf, S.U.; Cimatoribus, C.; Class, H.; Engesser, K.-H.; Helbich, S.; Hollert, H.; Lange, C.; Kranert, M.; Metzger, J.; Nowak, W.; et al. Anthropogenic Trace Compounds (ATCs) in aquatic habitats-Research needs on sources, fate, detection and toxicity to ensure timely elimination strategies and risk management. Environ. Int. 2015, 79, 85-105. [CrossRef] [PubMed]

10. EurEau. Treating Micropollutants at Waste Water Treatment Plants: Experiences and Developments from European Countries. Available online: http://www.eureau.org/resources/briefing-notes/3826-briefing-noteon-treating-micropollutants-at-the-wwtp/file (accessed on 13 May 2020). 
11. Antakyali, D.; Morgenschweis, K.; de Kort, T.; Herbst, H. Micropollutants in the Aquatic Environment and Their Removal in Wastewater Treatment Works: 9th European Waste Water Management Conference \& Exhibition 12-13 October, Manchester Town Hall. Available online: https://www.researchgate.net/publication/312879251_MICROPOLLUTANTS_IN_THE_AQUATIC_ ENVIRONMENT_AND_THEIR_REMOVAL_IN_WASTEWATER_TREATMENT_WORKS (accessed on 17 May 2020).

12. Metz, F. (Ed.) From Network Structure to Policy Design in Water Protection. A Comparative Perspective on Micropollutants in the Rhine River Riparian Countries; Springer International Publishing: Cham, Switzerland, 2017; ISBN 978-3-319-55693-2.

13. Siegrist, H.; Joss, A.; Boehler, M.; McArdell, C.S.; Ternes, T. Organic micropollutant control. In Advances in Wastewater Treatment; Mannina, G., Ekama, G., Ødegaard, H., Olsson, G., Eds.; IWA Publishing: London, UK, 2019.

14. BMU/UBA. Ergebnispapier-Ergebnisse der Phase 2 des Stakeholder-Dialogs »Spurenstoffstrategie des Bundes« zur Umsetzung von Maßnahmen für die Reduktion von Spurenstoffeinträgen in die Gewässer. 2019. Available online: https://www.bmu.de/download/ergebnisse-der-phase-2-des-stakeholder-dialogsspurenstoffstrategie-des-bundes/ (accessed on 9 July 2020).

15. VSA. Projekte mit Ozon. VSA-Plattform "Verfahrenstechnik Mikroverunreinigungen". 2019. Available online: https://www.micropoll.ch/anlagen-projekte/ozon/ (accessed on 28 February 2019).

16. IRENA. Renewable Capacity Statistics 2020. Available online: https://www.irena.org/publications/2020/Mar/ Renewable-Capacity-Statistics-2020 (accessed on 6 April 2020).

17. IRENA. Renewable Capacity Highlights. Available online: https://www.irena.org/-/media/Files/ IRENA/Agency/Publication/2020/Mar/IRENA_RE_Capacity_Highlights_2020.pdf?la=en\&hash= B6BDF8C3306D271327729B9F9C9AF5F1274FE30B (accessed on 31 March 2020).

18. Sterner, M.; Stadler, I. Handbook of Energy Storage. Demand, Technologies, Integration; Springer Berlin: Berlin, Germany, 2018; ISBN 978-3-662-55504-0.

19. Schäfer, M.; Gretzschel, O.; Steinmetz, H. The Possible Roles of Wastewater Treatment Plants in Sector Coupling. Energies 2020, 13, 2088. [CrossRef]

20. Schäfer, M. Short-term flexibility for energy grids provided by wastewater treatment plants with anaerobic sludge digestion. Water Sci. Technol. 2019. [CrossRef] [PubMed]

21. Schmitt, T.G.; Gretzschel, O.; Schäfer, M.; Hüesker, F.; Salomon, D.; Bidlingmaier, A.; Zdrallek, M.; Kornrumpf, T.; Simon, R.; Hanke, B.; et al. Abwasserreinigungsanlagen als Regelbaustein in intelligenten Verteilnetzen mit Erneuerbarer Energieerzeugung_Arrivee. Schlussbericht Arrivee. 2017. Available online: http://edok01.tib.uni-hannover.de/edoks/e01fb17/899010695.pdf (accessed on 13 December 2017).

22. Steinmetz, H.; Schmitt, T.G.; Schäfer, M.; Gretzschel, O.; Krieger, S.; Alt, K.; Zydorczyk, S.; Bender, V.; Pick, E. Konzeptstudie-Klimafreundliche und ressourceneffiziente Anwendung der Wasserelektrolyse zur Erzeugung von regenerativen Speichergasen kombiniert mit einer weitergehenden Abwasserbehandlung zur Mikroschadstoffelimination auf Kläranlagen-Arrived. Studie im Auftrag der Wirtschaftsbetriebe Mainz (Unpublished); Final Report; Tectraa an der TU Kaiserslautern: Kaiserslautern, Germany, 2018.

23. Rößler, A.; Rau, W.; Metzger, S. Vorkommen von Spurenstoffen in Kläranlagenzuläufen in Baden-Württemberg. Wasser und Abfall 2018, 40-49. Available online: https://koms-bw.de/cms/content/media/Vorkommen\%20von\% 20Spurenstoffen\%20in\%20Klaeranlagenzulaeufen\%20in\%20BW.pdf (accessed on 9 July 2020).

24. Schmitt, T.G.; Knerr, H.; Gretzschel, O.; Kolisch, G.; Taudien, Y. Relevanz, Möglichkeiten und Kosten einer Elimination von Mikroschadstoffen auf kommunalen Kläranlagen in Rheinland-Pfalz, aufgezeigt am Beispiel der Nahe- Mikro_N. Studie im Auftrag des Ministeriums für Umwelt, Landwirtschaft, Ernährung, Weinbau und Forsten (MULEWF) des Landes Rhein-land-Pfalz, Deutschland. 2016. Available online: https://wasser.rlp-umwelt.de/servlet/is/1130/ (accessed on 21 August 2018).

25. Vieno, N.; Sillanpää, M. Fate of diclofenac in municipal wastewater treatment plant-A review. Environ. Int. 2014, 69, 28-39. [CrossRef]

26. Sathishkumar, P.; Meena, R.A.A.; Palanisami, T.; Ashokkumar, V.; Palvannan, T.; Gu, F.L. Occurrence, interactive effects and ecological risk of diclofenac in environmental compartments and biota-A review. Sci. Total Environ. 2020, 698, 134057. [CrossRef]

27. Zhang, Y.; Geissen, S.-U.; Gal, C. Carbamazepine and diclofenac: Removal in wastewater treatment plants and occurrence in water bodies. Chemosphere 2008, 73, 1151-1161. [CrossRef] 
28. Umweltbundesamt. ETOX: Informationssystem Ökotoxikologie und Umweltqualitätsziele. Available online: https://webetox.uba.de/webETOX/public/search/ziel/open.do (accessed on 11 September 2018).

29. ICSR/IKSR. Micropollutants in the Rhine Catchment Area/Mikroverunreinigungen im Rheineinzugsgebiet Bilanz 2017: Bericht Nr. International Commission for the Protection of the Rhine (ICPR). Available online: https://www.iksr.org/en/public-relations/documents/archive/technical-reports/reports-and-brochuresindividual-presentation?tx_news_pi1\%5Baction\%5D=detail\&tx_news_pi1\%5Bcontroller\%5D=News\&tx_ news_pi1\%5Bnews\%5D=527\&cHash=7ec1cb6e82a0271e9bf7caa6b7dab3f8 (accessed on 10 April 2018).

30. Angerbauer, F. Spurenstoffmessung im Rhein an der Messstelle Mainz-Ergebnisse 2010. Personal communication via E-Mail, 2019.

31. DWA (Ed.) Energiecheck und Energieanalyse. Instrumente zur Energieoptimierung von Abwasseranlagen; DWA: Hennef, Germany, 2015; ISBN 978-3-88721-276-6.

32. DWA. Anthropogene Spurenstoffe, Krankheitserreger und Antibiotikaresistenzen im Wasserkreislauf. 2017. Available online: https://de.dwa.de/files/_media/content/01_DIE\%20DWA/Forschung\%20und\% 20Innovation/Anthropogene_Spurenstoffe_Krankheitserreger_TransRisk_Druckfassung_komprimiert20170130.pdf (accessed on 21 February 2019).

33. Böhler, M.; Blunschi, M.; Czekalski, N.; Fleiner, J.; Kienle, C.; Langer, M.; McArdell, C.S.; Teichler, R.; Siegrist, H. Biologische Nachbehandlung von kommunalem Abwasser nach Ozonung-ReTREAT. Abschlussbericht für das Bundesamt für Umwelt (Bafu) im Rahmen eines Projektes der Technologieförderung. 2017. Available online: http://www.oekotoxzentrum.ch/media/182953/2017_boehler_retreat_schlussbericht.pdf (accessed on 9 July 2020).

34. Östman, M.; Björlenius, B.; Fick, J.; Tysklind, M. Effect of full-scale ozonation and pilot-scale granular activated carbon on the removal of biocides, antimycotics and antibiotics in a sewage treatment plant. Sci. Total Environ. 2019, 649, 1117-1123. [CrossRef]

35. Rödel, S.; Günthert, W.; Christ, O.; Miller, E.; Schatz, R.; Zech, T.; Bleisteiner, S.; Eßlinger, M.; Sengl, M.; Rehbein, V.; et al. Erfahrungen und Ergebnisse aus dem Betrieb der vierten Reinigungsstufe in Weißenburg: Teil 1: Untersuchungsprogramm und Ergebnisse. KA Korrespondenz Abwasser Abfall 2019, 66, 200-209.

36. Baresel, C.; Ek, M.; Ejhed, H.; Allard, A.-S.; Magnér, J.; Dahlgren, L.; Westling, K.; Wahlberg, C.; Fortkamp, U.; Söhr, S.; et al. Sustainable treatment systems for removal of pharmaceutical residues and other priority persistent substances. Water Sci. Technol. 2019, 79, 537-543. [CrossRef] [PubMed]

37. Steinmetz, H.; Schmitt, T.G.; Schäfer, M.; Gretzschel, O.; Krieger, S.; Alt, K.; Zydorczyk, S.; Bender, V.; Pick, E. Ergänzende Betrachtungen zur Konzeptstudie „arrived“ Vorzugsvariante-. Studie im Auftrag der Wirtschaftsbetriebe Mainz (Unpublished); Final Report; Tectraa an der TU Kaiserslautern: Kaiserslautern, Germany, 2019.

38. Müller-Syring, G.; Henel, M.; Köppel, W.; Sterner, M.; Höcher, T. Entwicklung von modularen Konzepten zur Erzeugung, Speicherung und Einspeisung von Wasserstoff und Methan ins Erdgasnetz. Abschlussbericht-DVGW-Förderzeichen G 1-07-10; DVGW Forschung: 2013. Available online: https: //www.dvgw.de/medien/dvgw/forschung/berichte/g1_07_10.pdf (accessed on 9 July 2020).

39. Ateş, A. Cost of Reducing Micropollutant Load from Urban Wastewater Treatment Plants in Turkey. 2019. Available online: http://etd.lib.metu.edu.tr/upload/12625042/index.pdf (accessed on 17 May 2020).

40. Austermann-Haun, U.; Meier, J.F.; Nahrstedt, A.; Sikorski, D.; Kuhlmann, S.; Alt, K. Spurenstoffelimination auf der Kläranlage Detmold mittels der Kombination von Ozon mit nachgeschalteter Aktivkohlefiltration. Abschlussbericht, gerichtet an das Ministerium für Klimaschutz, Umwelt, Landwirtschaft, Natur- und Verbraucherschutz des Landes Nordrhein-Westfalen. 2017. Available online: https://www.lanuv.nrw.de/fileadmin/forschung/170815_Pilotvorhaben\%20Detmold/O-01-12-DTSpurenstoffelimination-KA-DT_Abschlussbericht.pdf (accessed on 12 October 2018).

41. Gretzschel, O.; Schäfer, M.; Steinmetz, H.; Schmitt, T.G. Combined Implementation of Power-to-Gas and Elimination of Micropollutants-A Feasibility Study for WWTP Mainz. In Proceedings of the 13th International Renewable Energy Storage Conference (IRES 2019), Düsseldorf, Germany, 12-14 March 2019.

42. Bhandari, R.; Trudewind, C.A.; Zapp, P. Life cycle assessment of hydrogen production via electrolysis-A review. J. Clean. Prod. 2014, 85, 151-163. [CrossRef]

43. Huneke, F.; Linkenheil, C.P.; Niggemeier, M.-L. Kalte Dunkelflaute: Robustheit des Stromsystems bei Extremwetter. Available online: https:/www.energybrainpool.com/fileadmin/download/Studien/Studie_ 2017-06-26_GPE_Studie_Kalte-Dunkelflaute_Energy-Brainpool.pdf (accessed on 4 May 2020). 
44. Sterner, M.; Stadler, I. Energiespeicher-Bedarf, Technologien, Integration, Auflage; Springer: Berlin/Heidelberg, Germany, 2017.

45. h2agentur. Wasserstoff zur Speicherung Erneuerbarer Energie: PEM-Elektrolyseure. Available online: https://h2agentur.de/elektrolyseure/ (accessed on 11 May 2020).

46. h2agentur. Pressure of the Oxygen Generated by PEM Electrolysis, Personal Confirmation by Phone from h2agentur to Stefan Krieger Hydroingenieure, Kaiserslautern, Germany: 2019.

47. Tjarks, G. PEM-Elektrolyse-Systeme zur Anwendung in Power-to-Gas Anlagen; Forschungszentrum Jülich GmbH, Zentralbibliothek: Jülich, Germany, 2017; ISBN 978-3-95806-217-7.

48. Mousel, D.; Palmowski, L.; Pinnekamp, J. Energy demand for elimination of organic micropollutants in municipal wastewater treatment plants. Sci. Total Environ. 2017, 575, 1139-1149. [CrossRef]

49. Pinnekamp, J.; Bolle, F.-W.; Palmowski, L.; Veltmann, K.; Mousel, D.; Mauer, C.; Eckers, S. Energiebedarf von Verfahren zur Elimination von organischen Spurenstoffen. Abschlussbericht zum gleichnamigen Forschungsprojekt, gefördert durch das Ministerium für Klimaschutz, Umwelt, Landwirtschaft, Natur- und Verbraucherschutz des Landes Nordrhein-Westfalen (MKULNV). 2011. Available online: http://www.lanuv. nrw.de/wasser/abwasser/forschung/pdf/Abschlussbericht_ENVELOS.pdf (accessed on 28 September 2012).

50. Hillenbrand, T.; Tettenborn, F.; Fuchs, S.; Tochovski, S.; Metzger, S.; Tjoeng, I.; Wermter, P.; Kersting, M.; Hecht, D.; WErbeck, N.; et al. Maßnahmen zur Verminderung des Eintrages von Mikroschadstoffen in die Gewässer—Phase 2. Available online: https://www.umweltbundesamt.de/sites/default/files/medien/377/ publikationen/mikroschadstoffen_in_die_gewasser-phase_2.pdf (accessed on 9 July 2020).

51. Altmann, J.; Rehfeld, D.; Träder, K.; Sperlich, A.; Jekel, M. Combination of granular activated carbon adsorption and deep-bed filtration as a single advanced wastewater treatment step for organic micropollutant and phosphorus removal. Water Res. 2016, 92, 131-139. [CrossRef]

52. Hamoda, M.F.; Al-Ghusain, I.; Al-Mutairi, N.Z. Sand filtration of wastewater for tertiary treatment and water reuse. Desalination 2004, 164, 203-211. [CrossRef]

53. Lardon, L.; Thorberg, D.; Krosgaard, L. Biogas valorization and efficient energy management-Technical and economic analysis of biological methanation. POWERSTEP Deliverable D 3. In Powerstep: Your Flush, Our Energy; Kompetenzzentrum, W.B., Ed.; Kompetenzzentrum Wasser Berlin: Berlin, Germany, 2018; Available online: http://powerstep.eu/system/files/generated/files/resource/d3-2-technical-and-economicanalysis-of-biological-methanationdeliverable.pdf (accessed on 16 March 2020).

54. Juhrich, $\mathrm{K} . \mathrm{CO}_{2}$-Emissionsfaktoren für Fossile Brennstoffe. Available online: https://www.umweltbundesamt. de/publikationen/co2-emissionsfaktoren-fuer-fossile-brennstoffe (accessed on 14 January 2019).

55. Koch, F. E-Busse mit Brennstoffzelle-Europäische Markteinführungsinitiative; EnergieAgentur NRW: Aachen, Germany, 2016.

56. Eichhammer, W.; Fleiter, T.; Schlomann, B. Energieverbrauch und $\mathrm{CO}_{2}$-Emissionen industrieller Prozesstechnologien. Einsparpotenziale, Hemmnisse und Instrumente; Fraunhofer-Verl.: Stuttgart, Germany, 2013; Available online: https://www.isi.fraunhofer.de/content/dam/isi/dokumente/ccx/2013/Umweltforschungsplan_FKZ370946130.pdf (accessed on 9 July 2020).

57. UBA. ProBas-Prozessorientierte Basisdaten für Umweltmanagementsysteme. Available online: http: //www.probas.umweltbundesamt.de/php/index.php (accessed on 17 December 2018).

58. Schutzgemeinschaft Deutscher Wald, S.D.W. Was leistet der Wald für uns? Available online: https: //www.sdw.de/waldwissen/oekosystem-wald/waldleistungen/index.html (accessed on 4 May 2020).

59. Huneke, F. Auf dem Weg in die Wettbewerbsfähigkeit: Elektrolysegase erneuerbaren Ursprungs. 2018. Available online: https:/www.energybrainpool.com/fileadmin/download/Studien/Kurzanalyse_2018-0319_GPE_Kurzanalyse_Kostenentwicklung-von-Elektrolysegas-erneuerbaren-Ursprungs.pdf (accessed on 5 May 2020).

60. Greenpeace Energy. Unser Windgas im Detail. Available online: https://www.greenpeace-energy.de/ privatkunden/oekogas/unser-windgas-im-detail.html (accessed on 18 May 2020).

61. Parra, D.; Zhang, X.; Bauer, C.; Patel, M.K. An integrated techno-economic and life cycle environmental assessment of power-to-gas systems. Appl. Energy 2017, 193, 440-454. [CrossRef]

62. Blanco, H.; Faaij, A. A review at the role of storage in energy systems with a focus on Power to Gas and long-term storage. Renew. Sustain. Energy Rev. 2018, 81, 1049-1086. [CrossRef]

63. Eveloy, V.; Gebreegziabher, T. A Review of Projected Power-to-Gas Deployment Scenarios. Energies 2018, 11, 1824. [CrossRef] 
64. Thema, M.; Bauer, F.; Sterner, M. Power-to-Gas: Electrolysis and methanation status review. Renew. Sustain. Energy Rev. 2019, 112, 775-787. [CrossRef]

65. Erneuerbare-Energien-Gesetz-EEG 2017/Renewable Energy Sources Act. (EEG 2017). EEG. 2020. Available online: https://www.bmwi.de/Redaktion/DE/Downloads/E/eeg-2017-gesetz-en.pdf?_blob=publicationFile\& $\mathrm{v}=8$ (accessed on 19 May 2020).

66. BDEW. BDEW-Strompreisanalyse 2020. Available online: https://www.bdew.de/energie/strom-undgaspreisanalysen/ (accessed on 18 May 2020).

67. 50Hertz Transmission GmbH, Amprion GmbH, TransnetBW GmbH, Tennet TSO GmbH. EEG-Umlage. Available online: https://www.netztransparenz.de/EEG/EEG-Umlagen-Uebersicht (accessed on 19 May 2020).

68. regelleistung.net. Balancing Market in Germany. Available online: https://www.regelleistung.net/ext/static/ market-information?lang=en (accessed on 29 June 2020).

69. Bui, X.T.; Vo, T.P.T.; Ngo, H.H.; Guo, W.S.; Nguyen, T.T. Multicriteria assessment of advanced treatment technologies for micropollutants removal at large-scale applications. Sci. Total Environ. 2016, 563-564, 1050-1067. [CrossRef] [PubMed]

70. Alt, K. Umnutzung vorhandener Flockungsfiltrationsanlagen zu Aktivkohle- und Ozonanlagen; 50 Jahre Oswald-Schulze Stiftung; Technische Innovationen in der Abwasserreinigung: Münster, Germany, 2018.

(C) 2020 by the authors. Licensee MDPI, Basel, Switzerland. This article is an open access article distributed under the terms and conditions of the Creative Commons Attribution (CC BY) license (http://creativecommons.org/licenses/by/4.0/). 